\title{
Snemmtæk íhlutun í lestrarnámi í 1. bekk
}

\author{
Elva Eir Pórólfsdóttir, Guðmundur Engilbertsson og Porlákur Axel Jónsson
}

Abstract Um höfundana About the authors $>$ Heimildir

Í greininni er sagt frá rannsókn á áhrifum snemmtækrar íhlutunar í lestrarnámi. Í íhlutuninni var notað stuðningskerfið Leið til lasis en pað er ætlað kennurum á yngsta stigi grunnskóla til að finna pau börn sem eiga á hættu að lenda í lestrarerfiðleikum annars vegar og til að skipuleggja íhlutun og meta áhrif af henni hins vegar. Stuðningskerfið Leið til lasis samanstendur af handbók, lesskimunarprófi og eftirfylgdarprófum í lesfimi og sjónrænum orðaforða.

Rannsóknin fólst í pví að skima fyrir mögulegum lestrarerfiðleikum hjá börnum í 1. bekk í einum grunnskóla og veita peim viðeigandi íhlutun í hljóðkerfisvitund, stafapekkingu og málproska. Rannsóknin nádi yfir fyrsta vetur barnanna í grunnskóla. Íhlutunartímabilin voru prjú og stóðu pau yfir í sex vikur hvert. Áhrif voru metin með eftirfylgdarprófum í lesfimi og sjónrænum orðaforða. Framfarir barna í íhlutunarhópi voru bornar saman við framfarir peirra barna í árganginum sem ekki voru talin purfa sérstaka íhlutun samkvæmt niðurstöðum skimunarinnar. Heildarfjöldi barna í rannsókninni var 39. Par af voru 14 börn í íhlutunarhópi og 25 börn í samanburðarhópi.

Niðurstöður rannsóknarinnar benda til pess að áhrif snemmtækrar íhlutunar með Leið til lasis séu jákvæð á heildina litið. Öll börn í íhlutunarhópi sýndu framfarir. Horft var til kenningar Stanovich um Matteusar-áhrif par sem segir að börn sem eiga í erfiðleikum í lestrarnámi eigi á hættu að dragast aftur úr peim börnum sem gengur vel og bilið milli pessara hópa muni pví aukast með tímanum. Samkvæmt niðurstöðum rannsóknarinnar jókst bilið ekki á milli hópanna og náði íhlutunarhópur að halda í við framfarir samanburðarhóps.

Efnisorð: Lestur, lestrarerfiðleikar, forspárgildi, snemmtæk íhlutun, Leið til loesis

\section{Inngangur}

Dýðingarmikið er fyrir velgengni í námi og lífinu almennt að ná góðum tökum á lestri. Leita parf allra leiða til að bæta stöðu barna sem standa höllum fæti í lestrarnáminu, nota árangursríkustu aðferðirnar sem kostur er á og grípa inn í, ef pörf er, sem allra fyrst í upphafi lestrarnámsins (Lane, Pullen, Hudson og Konold, 2009; Mennta- og menningarmálaráðuneytið, 2013).

Á árum áđur var viðtekin venja að bíða með að grípa inn í með sérhæfðum aðgerðum ef börn áttu í erfiðleikum í upphafi lestrarnámsins. Detta var gert á peim forsendum að börnin væru ekki tilbúin til að hefja lestrarnámið og pyrftu að fá tækifæri til að proskast (Steinunn Torfadóttir, 2011b). Í pessu viðhorfi felst hætta á að erfiðleikar barnanna aukist. Рað getur torveldað að pau 
nái aldurssvarandi tökum á lestri og hætta er á að dýrmætur tími glatist. Рað sem einkennir snemmtæka íhlutun er sérhæfð nálgun par sem leitast er við að svara peirri spurningu hvað hentar hverjum best og hvers vegna. Dá er talið mikilvægt að hefja íhlutun eins snemma og hægt er, eða um leið og grunur vaknar um erfiðleika (Steinunn Torfadóttir, 2011b; Tryggvi Sigurðsson, 2004, 2008). Hugmyndafræði snemmtækrar íhlutunar sækir pekkingu sína og rökstuðning pvert á fræðigreinar. Á grunni hennar hefur í auknum mæli verið gerð grein fyrir pví hvernig megi með markvissum aðgerðum hafa áhrif á proskaframvindu barna, hvort heldur sem er í vitsmuna-, mál-, félags- eða hreyfiproska (Elliot og Grigorenko, 2014; Tryggvi Sigurðsson, 2004, 2008).

Líkt og orðið sjálft gefur til kynna byggist snemmtæk íhlutun á að bregðast fljótt og örugglega við erfiðleikum, í pessu tilviki lestrarerfiðleikum, og veita íhlutun við hæfi (Helga Sigurmundsdóttir, e.d.; Snowling, 2013). Dað er mikilvægt fyrir margar sakir. Augljóst er að snemmtæk íhlutun getur komið í veg fyrir lestrarvanda og um leið minnkað líkurnar á pörf fyrir sérkennslu seinna meir (González-Valenzuela og Martín-Ruiz, 2017; Riley, 2006). Farsælt lestrarnám frá upphafi gefur barninu meðbyr í námi og ýtir undir frekari velgengni í öđrum námsgreinum. Ófullnægjandi lestrarlag getur fest í sessi og síðan reynst erfitt að leiðrétta pað seinna meir. Pá getur sjálfstraust og trú barnsins á eigin getu beðið hnekki gangi pví ekki vel að læra að lesa, sem getur síðan haft víðtæk neikvæð áhrif á líðan og nám (Riley, 2006). Kveikjan að rannsókn okkar var að leita leiða til pess að veita börnum sem eiga í erfiðleikum með lestrarnámið markvissa kennslu við hæfi. Til að nálgast petta markmið var ákveðið að nota stuðningskerfið Leið til losis en pað er byggt á hugmyndafræði snemmtækrar íhlutunar og einstaklingsmiðaðrar lestrarkennslu (Steinunn Torfadóttir, 2011a).

Markmið rannsóknarinnar var að finna, með Leið til lessis: lesskimun, börn sem eiga á hættu аð lenda í lestrarerfiðleikum og veita peim viðeigandi íhlutun. Sett var fram sú tilgáta að með markvissri og öflugri íhlutun strax við upphaf 1. bekkjar mætti draga úr eða fyrirbyggja mögulega lestrarerfiðleika hjá börnum sem ættu á hættu að lenda í vanda í lestrarnáminu. Hér verður leitast við að svara eftirfarandi spurningum:

- Hver eru áhrif snemmtækrar íhlutunar, með Leið til locsis, á lestrarnám barna sem greinst hafa 1 áhættuhópi?

- Er hægt með snemmtækri íhlutun í hljóðkerfisvitund, stafapekkingu og eflingu málproska, að minnka líkurnar á pví að börn sem eru í áhættuhópi dragist enn frekar aftur úr jafnöldrum?

\section{Fræðilegur bakgrunnur}

Stanovich (1986) setti fram kenningu um Matteusar-áhrif í lestri sem felur í sér í yfirfærðri merkingu að hinir ríku verða ríkari og fátæku fátækari. Degar börnum gengur vel í lestrarnáminu lesa pau meira en börn sem gengur pað ver. Pau auka stöðugt við pekkingu sína og lestrarfærni og bilið á milli peirra sem gengur vel og illa í lestrarnáminu breikkar eftir pví sem líður á skólagönguna. Sideridis (2011) skoðaði rannsóknir par sem viðfangsefnið var að greina Matteusaráhrif yfir lengri tíma hjá börnum sem áttu við námserfiðleika að stríða. Niðurstöðurnar sýndu að mikilvægt væri að veita peim sem væru í vanda íhlutun við hæfi svo hægt væri að vinna gegn Matteusar-áhrifum.

Samkvæmt pessu er mikilvægt að horfa til pátta sem hafa forspárgildi um lestrarnám barna og grípa inn í lestrarnámið strax í upphafi ef vísbendingar eru um mögulega erfiðleika. Deir pættir sem eru sagðir hafa hvað mest forspárgildi eru hljóðkerfisvitund, stafapekking og málproski (Foorman, Herrera, Petscher, Mitchell og Truckenmiller, 2015; Muter, 2006; Schatschneider, Fletcher, Francis, Carlson og Foorman, 2004; Snowling, 2006). 


\section{Forspárgildi fyrir lestrarnám}

Hljóðkerfisvitund er hugtak sem vísar til pekkingar á hljóðum tungumálsins og skilnings á að hægt sé að skipta málinu í einingar og vinna með pær á ólíka vegu (Rósa Eggertsdóttir og Póra Björk Jónsdóttir, 2006; Scanlon, Anderson og Sweeney, 2017). Hljóðkerfisvitund er undirstaða skilnings á málum sem byggjast á stafrófi og eru bein tengsl á milli hennar og lesturs. Undir eðlilegum kringumstæðum tileinka börn sér hljóðkerfi móðurmálsins með pví að hlusta og leika sér með málhljóðin. Dað er hluti af proskaferli peirra yfir ákveðinn tíma. Sá broski er mikilvæg undirstaða fyrir lestrarnám (Ásthildur Bj. Snorradóttir, 2010). Sum börn eru lengi að próa með sér vitneskju um að tungumálinu megi skipta niður í orð, atkvæði og einstök hljóð á meðan önnur börn próa pessa færni auðveldlega og án leiðsagnar (Scanlon o.fl., 2017). Börn með slaka hljóðkerfisvitund við upphaf skólagöngu hafa litla tilfinningu fyrir einstaka hljóðum í málinu og eiga í erfiðleikum með að veita ólíku mynstri hljóða í orðum athygli án aðstoðar. Ef barn áttar sig ekki á að orð eru samsett úr mismunandi hljóðum hafa stafirnir sem mynda orð litla pýðingu fyrir pað (Torgesen, 2002). Góð færni í tengslum stafs og hljóðs er forsenda pess að ná góðum árangri í lestri (Scanlon o.fl., 2017). Samkvæmt Vellutino, Fletcher, Snowling og Scanlon (2004) eru óörugg tengsl hljóðs og stafs og rýr orðpekking yfirleitt vandi sem tengist slakri hljóðkerfisvitund og veldur erfiðleikum við að tengja á milli tal- og ritmáls.

Málproski felur í sér fjölbreytta pekkingu og færni sem er háð bæði meðfæddum eiginleikum og uppeldisáhrifum. Frá upphafi máltöku og fram á grunnskólaár læra börn orð og merkingu peirra, framburð, beygingar og hvernig raða má orðum saman á mismunandi hátt til að fá fram ólíka merkingu. Einnig tileinka pau sér frásagnarhæfni sem krefst pess að mörgum setningum er fléttað saman í samfellda heild (Hrafnhildur Ragnarsdóttir, 2004). Strax á leikskólaaldri próa börn með sér mikilvæga færni í tungumálinu sem hefur áhrif á lestrarnámið. Pau öðlast tilfinningu fyrir prentmáli, leika sér með málhljóð, atkvæði og orð og öðlast áhuga á lestri og ritun. Börn byggja lestrarnám sitt á peim orðaforða sem pau hafa byggt upp frá unga aldri og gerir lesturinn merkingarbæran fyrir peim (Pence og Justice, 2014). Seinkaður málproski er oft fyrsta vísbending um að barn geti átt við lestrarerfiðleika að stríða, en peir erfiðleikar koma yfirleitt ekki í ljós fyrr en barnið byrjar í skóla. Degar skólaganga hefst er gert ráð fyrir að börn hafi náð nokkuð góðum tökum á móðurmáli sínu. Ef vald peirra á málinu er ekki nægjanlegt getur pað haft neikvæð áhrif á lestrarfærni peirra (Catts, Fey, Tomblin og Zhang, 2002; Snowling, 2006). Catts o.fl. (2002) komust að peirri niðurstöðu um börn með málproskavanda að helmingur peirra ætti í lestrarerfiðleikum og hin væru í mörgum tilvikum slakir lesarar. Að auki eiga börn sem eru enn með seinkaðan málproska í grunnskóla frekar á hættu að eiga í lestrarerfiðleikum en börn sem bæta málproska sinn í upphafi skólagöngunnar. Í langtímarannsókn sem Jóhanna Einarsdóttir, Ingibjörg Símonardóttir og Amalía Björnsdóttir (2011) gerðu á forspárgildi athugana á málproska, mælt með HLJÓM-2 og TOLD-2P, komu fram tengsl málproskamælinga við fimm ára aldur og námsgengis, samkvæmt niðurstöðum á samræmdum prófum í grunnskóla. Dau börn sem sýndu góða færni í málproska við fimm ára aldur sýndu einnig góðan árangur á samræmdum prófum. Pessi tengsl haldast alla grunnskólagönguna og ná ekki aðeins til íslensku heldur einnig stærðfræði, ensku, dönsku og náttúrufræði.

\section{Snemmtæk íhlutun}

Lykilatriði er að skima fyrir áhættupáttum hjá börnum strax við upphaf skólagöngu svo hægt sé að veita peim börnum sem eru 1 áhættuhópum viðeigandi kennslu strax frá upphafi. Mikilvægt er að kortleggja hvar veikleikarnir eru, svo hægt sé að veita íhlutun við hæfi. Jafnframt er mikilvægt аð leggja markvisst mat á framvindu. Вað veitir upplýsingar um hvort barnið svari íhlutuninni, árangurinn sé ásættanlegur og hvort halda eigi íhlutuninni áfram eða nota frekar aðrar aðferðir til að ná árangri (Carroll, Bowyer-Crane, Duff, Hulme og Snowling, 2011). Börn í áhættuhópum búa ekki yfir sömu færnipáttum og jafnaldrar peirra utan áhættuhópa. Til pess að minnka bilið milli pessara hópa, og jafnvel eyða pví alveg, purfa börn í áhættuhópum að læra meira yfir sama tímabil. Dau purfa að fá öfluga íhlutun og markvissa kennslu í peim færnipáttum sem pau sýna veikleika í (Scanlon o.fl., 2017). 
Eins og áður hefur komið fram eru hljóðkerfisvitund, orðaforði og málskilningur peir pættir málproskans sem skipta meginmáli hvað lestur varðar. Til pess að forðast að barn lendi í erfiðleikum með lestur og nám er pví mikilvægt að vinna með fyrrgreinda pætti, samkvæmt hugmyndafræði snemmtækrar íhlutunar. Hún gengur út á að gera sér grein fyrir peim frávikum hjá börnum sem eru líkleg til að lenda í lestrarerfiðleikum og veita peim sem allra fyrst kennslu við hæfi (Scanlon o.fl., 2017; Ásthildur Bj. Snorradóttir, 2010).

Í rannsókn í 35 skólum í Bandaríkjunum á áhrifum íhlutunar í lestrarkennslu kom fram að íhlutun pyrfti að vera snemmtæk til pess að bera árangur. Síðasta árið í leikskóla og fyrstu tvö árin í grunnskóla bar íhlutun góðan árangur en sýndi hvorki jákvæð né neikvæð áhrif frá 3. og upp í 5. bekk (Hanselman og Borman, 2013). Í langtímarannsókn sem Partanen og Siegel (2014) gerðu var sýnt fram á að snemmtæk íhlutun bar góðan árangur og fækkaði börnum sem áttu í lestrarerfiðleikum síðar á skólagöngunni. Niðurstöður úr langtímarannsókn González-Valenzuela og Martín-Ruiz (2017) sýndu að íhlutun jók hæfni barna í lesfimi og að marktækur munur væri á milli íhlutunarhóps og samanburðarhóps. Ekki hafa verið gerðar margar íslenskar rannsóknir par sem áhrif snemmtækrar íhlutunar eru könnuð. Guðrún Bjarnadóttir (2004) kannaði áhrif Markvissrar málörvunar sem er kennsluefni í hljóðkerfisvitund. Niðurstöður sýndu að íhlutun jók hæfni barnanna í hljóðkerfisvitund.

Mikill einstaklingsmunur getur verið á pví hvernig börn bregðast við peirri íhlutun sem pau fá. Dau sýna ekki öll framfarir. Að meðaltali eiga um 5\% barna enn í lestrarerfiðleikum prátt fyrir íhlutun (Torgesen, 2002).

\section{Leið til loesis}

Leið til lasis er stuðningskerfi byggt á hugmyndafræði snemmtækrar íhlutunar og einstaklingsmiðaðrar lestrarkennslu (Steinunn Torfadóttir, 2011a). Leið til laesis skiptist 1 handbók, lesskimun fyrir 1. bekk og eftirfylgdarpróf í lesfimi og sjónrænum orðaforða fyrir 1. til 4. bekk. Lesfimi er skilgreind sem færni sem byggir á nákvæmni, sjálfvirkni og hrynrænum páttum tungumálsins. Lesfimin birtist í fyrirhafnarlausum og sjálfvirkum lestri (Khun, Schwanenflugel og Meisinger, 2010). Nákvæmni felur í sér hlutfall rétt lesinna orða miðað við heildarfjölda orða sem lesinn er. Sjálfvirkni segir til um hversu hratt og fyrirhafnarlaust er lesið og án áreynslu. Hrynrænir pættir tungumálsins segja til um hnig og ris raddarinnar par sem lesið er af innlifun með réttu hljómfalli svo merking komist vel til skila (Helga Sigurmundsdóttir, 2011b). Sjónrænn orðalestur byggir á að pekkt orð eru sótt í minnið. Börn sem eru að byrja að læra að lesa geta lært að pekkja orð sjónrænt eftir að hafa séð pað einungis fjórum sinnum. Dá er orðið lesið sem ein heild án pess að gert sé hlé á milli hljóða og mun hraðar en hægt væri að lesa með umskráningu. Með aukinni lestrarfærni geta öll orð verið lesin með sjónrænum lestri. Sá sem býr yfir góðum sjónrænum orðaforða getur lesið án fyrirhafnar og einbeitt sér betur að pví sem lesið er (Ehri, 2002).

Upphaflega gaf Námsmatsstofnun út Leið til laesis en í dag gefur Menntamálastofnun efnið út undir heitinu Lesferill (Menntamálastofnun, e.d.). Í nýju útgáfunni er handbókin og lesskimunin í sömu mynd og var í Leið til lesis. Í Lesferli eru grunnpróf sem eru próf í lesfimi líkt og í Leið til lasis og hliðarpróf sem eru próf í sjónrænum orðaforða líkt og í Leið til lesis, auk hliðarprófs 1 orðleysulestri, en orðleysur eru bullorð sem pýða ekki neitt (Menntamálastofnun, e.d.). Í umfjöllun sem hér fer á eftir er notað heitið Leið til lassis par sem efnið bar pað heiti pegar pessi rannsókn var framkvæmd og einnig par sem ekki er um nákvæmlega sömu próf að ræða og Lesferill inniheldur.

Að hausti í 1. bekk er Leið til lassis: lesskimun (Steinunn Torfadóttir o.fl., 2011) lögð fyrir en par er undirstaða í læsispáttum könnuð (Sigurgrímur Skúlason og Jóhanna Ella Jónsdóttir, 2011). Ekki er gert ráð fyrir að börnin séu byrjuð að lesa pegar lesskimunin er lögð fyrir og pví er ekki verið að prófa lestrarfærni með lesskimuninni. Prófið veitir niðurstöður í premur aðskildum færnipáttum 
en peir eru hljóðkerfisvitund, bókstafir og hljóð og málproski. Til að túlka og nýta niðurstöður lesskimunarinnar er stuðst við áhættuflokkun sem byggir á stöðlun prófsins, út frá öllum premur prófhlutunum en pá er hópurinn brotinn upp eftir pví hversu miklar líkur eru taldar vera á pví að börn geti lent í erfiðleikum í lestrarnáminu. Áhættuflokkunin er eftirfarandi: Miklar líkur á vandkvæðum telst vera áhœetta 1, nokkrar líkur á vanda flokkast sem áhœetta 2, hugsanleg pörf á stuðningi sem óvissa og loks eru nemendur utan áhattu (Steinunn Torfadóttir o.fl., 2011). Að lagskipta áhættuflokkum með pessum hætti gerir kennara meðvitaðan um breytilega stöðu barna 1 áhættuhópum og með viðeigandi kennslu geta sum peirra náð fljótt góðum árangri (Helga Sigurmundsdóttir, 2011a).

Með Leið til laesis fylgja stöðluð eftirfylgdarpróf sem skiptast í tvennt; sjónrænan orðaforða og lesfimi. Prófin mæla tvær mikilvægar hliðar lesturs: Lesfimi metur leshraða í samfelldum texta en sjónræni orðaforðinn metur pann orðaforða sem barnið pekkir beint án pess að beita hljóðrænni umskráningu við lesturinn. Prófin staðsetja barnið með tilliti til jafnaldra á landinu öllu og miðar stöðlun við frammistöðu barns að vori. Eftirfylgdarprófin sýna hversu mörg orð á mínútu barnið les, og raðeinkunn fyrir leshraða. Raðeinkunn í Leið til laesis er byggð upp með peim hætti að helmingur barna fær raðeinkunn hærri en 50 og hinn helmingurinn lægri en 50. Dví má túlka frammistöðu einstakra barna með raðeinkunn í námunda við 50, til dæmis á bilinu 35 til 65, sem miðlungs frammistöðu. Jafnframt má túlka pær raðeinkunnir sem eru lægri en miðlungs raðeinkunnir sem slaka frammistöðu og pær sem eru hærri en miðlungs sem góða frammistöðu. Dær raðeinkunnir sem liggja nálægt neðri og efri mörkum má enn fremur túlka sem mjög slaka og mjög góða frammistöðu (Námsmatsstofnun, e.d.-a).

Með Leið til laesis fylgir einnig handbók. Dar má meðal annars finna leiðbeiningar um hvernig megi sporna við mögulegum lestrarvanda, hvað taki við í framhaldi af lesskimun og leiðbeiningar um pjálfun fyrir börn sem eru í áhættu að lenda í erfiðleikum með lestrarnám. Ekki hafa verið gerðar margar rannsóknir á gagnsemi stuðningskerfisins Leið til lasis en pó hefur pað sýnt sig að reynsla og gagnsemi af stuðningskerfinu er almennt talin vera gagnleg eða mjög gagnleg af umsjónarkennurum, sérkennurum og deildarstjórum í yngstu bekkjum grunnskólans (Rakel Magnúsdóttir, 2016).

\section{Аðferð}

Gerð var óslembuð samanburðarrannsókn með hálftilraunasniði, sem felur í sér að með sömu prófum var frammistaða tveggja hópa barna borin saman par sem annar hafði notið snemmtækrar íhlutunar en hinn ekki. Tilraunasnið pykja sterk rannsóknarsnið en pau fela í sér að gera breytingu á gildi einnar breytu sem nefnist óhád breyta og athuga áhrif hennar á útkomubreytu sem nefnist hád breyta (Cohen, Manion og Morrison, 2000). Í rannsóknum í skólastofunni er óháđa breytan iðulega einhvers konar hvatning, örvun eða íhlutun og háða breytan viðbrögð við pví. Hér er hin snemmtæka íhlutun óháđa breytan sem er mismunandi milli hópa en frammistaðan á prófum sem fylgja Leið til leesis og allir taka er hin háda útkomubreyta. Hálftilraunasnið er frábrugðið tilraunasniði hvað varðar að ekki er skipað handahófskennt í tvo hópa par sem hending ræður síðan hvor peirra verður tilraunarhópur sem fær íhlutun og hvor samanburðarhópur sem fær hana ekki (Cohen o.fl., 2000). Í pessari rannsókn var ekki slembivalið í hópana, börnin voru valin í tilraunarhóp og samanburðarhóp. Detta dregur úr möguleikum á að álykta að íhlutunin ein hafi áhrif á háđu breytuna og ekki aðrir pættir (Ragnheiður Harpa Arnardóttir, 2013).

\section{Pátttakendur}

Dátttakendurnir í rannsókninni voru börn í 1. bekk í einum skóla á Akureyri. Í árganginum voru tvær bekkjardeildir, í annarri peirra voru 17 börn en í hinni 22, samtals 39 börn. Drengirnir voru 23 og stúlkurnar 16. Öll börn í árganginum fengu kennslu í samræmi við niðurstöður úr Leið til lasis: lesskimun, en pau börn sem flokkuðust 1 áhættu 1 eftir lesskimunina fengu sérstaka 
íhlutun út frá áhættupáttunum. Að lokinni lesskimun voru 8 börn í íhlutunarhópi. Eftir fyrsta íhlutunartímabil og fyrstu mælingu, par sem lesfimi og sjónrænn orðaforði var mældur, höfðu kennarar töluverðar áhyggjur af hópi barna sem hafði ekki náð peim árangri sem peir væntu. Um var að ræða 6 börn sem öll voru ýmist í áhættu 2 eða flokkuðust undir óvissu í einum eða tveimur páttum, samkvæmt lesskimuninni. Dar sem pessi börn sýndu fram á svipaðan eða lakari árangur en börnin sem voru í íhlutunarhópnum voru uppi hugmyndir um að skipta út peim börnum sem höfðu staðið sig best í íhlutunarhópnum í stað pessara barna. Eftir miklar vangaveltur var hins vegar ákveðið að bæta pessum börnum frekar inn í hópinn par sem ekki pótti ráðlagt að sleppa strax hendinni af peim börnum sem upphaflega voru í íhlutunarhópnum. Börnin í íhlutunarhópnum voru pví orðin 14 talsins. Í samanburðarhópnum voru 25 börn, 14 peirra höfðu verið utan áhattu í öllum páttum, 9 höfðu skimast í áhættu 2 eða óvissu í einum pætti og 2 í tveimur páttum. Detta varð til pess að ekki fengu öll börn í íhlutunarhópnum kennslu öll íhlutunartímabilin, sum fengu tvö íhlutunartímabil af premur. Detta skoðast sem takmörkun á ályktunum um áhrif íhlutunarinnar á lestrarnámið.

\section{Framkvæmd og gagnavinnsla}

Öflun gagna hófst í október 2013 og lauk í maí 2014. Leið til lasis: lesskimunarpróf var lagt fyrir hópinn í byrjun október. Leið til laesis: eftirfylgdarpróf í lesfimi og sjónrænum orðaforða voru lögð fyrir prisvar sinnum yfir veturinn; í desember, mars og maí. Miðað var við að svipuð tímalengd væri á milli allra prófanna, eða um sex kennsluvikur.

Áhæettupættirnir í lesskimuninni eru prír; hljóðkerfisvitund, bókstafir og hljóð og málproski. Fyrst voru íhlutunarhóparnir prír, einn í hverjum áhættupætti. Eftir fyrsta íhlutunartímabil fjölgaði hópunum í fjóra og voru pá tveir hópar í hljóðkerfisvitund. Íhlutunin var í premur sex vikna lotum. Við skipulagningu á henni var stuðst við Leið til loesis: handbók en par er að finna hugmyndir og leiðbeiningar við kennslu barna sem purfa frekari pjálfun í peim áhættupáttum sem lesskimunin mælir. Í fyrstu lotunni fékk hver hópur 20 mínútna kennslu, fjórum sinnum 1 viku. Fyrsti höfundur greinarinnar veitti íhlutunina. Eftir fyrstu lotuna fjölgaði hópunum úr premur í fjóra. Hver hópur fékk pví 15 mínútna kennslu, fjóra daga vikunnar í stað 20 mínútna ádur.

Óháđa breytan í rannsókninni var íhlutunin sem veitt var í kjölfar lesskimunarinnar. Háđa breytan í rannsókninni var árangur af íhlutuninni. Fyrsta mælingin var Leið til locsis: lesskimun, en par sem hún á að fara fram við upphaf 1 . bekkjar er ekki gert ráð fyrir að börnin kunni að lesa og er pví ekki verið að prófa lestrarfærni.

Leið til lasis: eftirfylgdarpróf mæla lestrarfærni og gera mögulegt að mæla árangur af íhlutuninni. Prófin mæla tvær mikilvægar hliðar lesturs; lesfimi og sjónrænan orðaforða. Hægt er að staðsetja barnið með tilliti til jafnaldra á landinu öllu, líkt og með lesskimuninni. Eftirfylgdarprófin sýna leshraða, pað er hversu mörg orð á mínútu barnið les, ásamt raðeinkunn fyrir leshraða en raðeinkunnin miðast við stöðlun prófsins að vori (Námsmatsstofnun, e.d.-b). Bæði prófin gefa niðurstöðu á samfelldum jafnbilakvarða (hafa ákveðna röð og jafn langt á milli gilda á kvarðanum). Mælikvarðinn fyrir leshraða er óskertur en par sem viðmið raðeinkunna er aldursbundið er kvarðinn skertur að pví leyti að efri mörk hans takmarka breytileikann meðal peirra sem best gengur á prófunum (Field, 2018).

Gerður var samanburður á upphafsmælingu og mælingum eftir hvert íhlutunartímabil par sem framfarir pátttakenda voru athugaðar. Lágmarks viðmiðið fyrir árangur í lestrarnáminu, sem sett var í rannsókninni, var raðeinkunn 35. Í tölfræðiprófum var miðað við 95\% öryggismörk $(p<0,05)$. Gerð var eftir á aflgreining með forritinu $\mathrm{G}^{\star}$ Power 3.1.9.2 (Faul, Erdfelder, Lang og Buchner, 2007) til pess að athuga hvort nægur fjöldi væri í úrtaki til pess að gera pá dreifigreiningu sem varð fyrir valinu. 
Tölfræðileg greining fór fram með IBM SPSS (e. Statistical Package for the Social Sciences) útgáfu 23. Sett er fram lýsandi tölfrææi fyrir greiningu á nemendahópnum og skiptingu hans í íhlutunarhóp og samanburðarhóp. Settar eru fram töflur fyrir meðaltöl á prófunum yfir tímabilið hjá hópunum og myndir sem sýna breytingarnar. Settar eru fram myndir sem sýna framfarir hjá einstaka börnum 1 íhlutunarhópnum. Sett er fram fylgnitafla fyrir tengsl háðu breytanna. Gerð var skipt dreifigreining á mun meðaltala milli hópa og innan hópa fyrir endurteknar mælingar (e. mixed between-within subjects analysis of variance) (Pallant, 2013). Niðurstaðan er sett fram sem $F$-gildi og áhrifastærðin sem eta í öðru veldi $\left(\eta^{2}\right)$.

\section{Niðurstöður}

Í pessum kafla er gerð grein fyrir niðurstöðum úr lesskimun og hvernig börnin röðuðust í hópa samkvæmt henni. Fjallað er um forsendur pess að gera skipta dreifigreiningu á gögnunum sem aflað var. Í framhaldi verða skoðaðar niðurstöður úr premur eftirfylgdarprófum í lesfimi annars vegar og sjónrænum orðaforða hins vegar með samanburði á íhlutunarhópnum og samanburðarhópnum.

\section{Niðurstöður lesskimunar}

Í töflu 1 má sjá niðurstöđur lesskimunarinnar par sem fjöldi barna er tilgreindur eftir áhættupáttum.

Tafla 1. Niðurstöður lesskimunar, fjöldi barna.

\begin{tabular}{lccc}
\hline & Málbroski & Stafapekking & Hljóðkerfisvitund \\
\hline Áhatta 1 & 1 & 3 & 5 \\
Áhatta 2 & 4 & 4 & 11 \\
Óvissa & 1 & 2 & 7 \\
Utan áhattu & 33 & 30 & 16 \\
\hline
\end{tabular}

Íhlutunarhóparnir voru prír, einn í hverjum áhættupætti og innihéldu peir börn sem voru í áhættu 1 í hverjum pætti. Börnin sem fengu íhlutun eftir lesskimun voru átta en sjö peirra höfðu skimast 1 áhættu 1 í einum pætti og eitt í tveimur páttum. Barnið sem skimaðist í áhættu 1 í tveimur páttum skimaðist í málproska og hljóðkerfisvitund. Par sem ekkert annað barn skimaðist í áhættu 1 í málproska var pað barn eitt í íhlutun par sem báđir bættirnir voru pjálfaðir samhliða.

\section{Niðurstöður eftir fyrstu fyrirlögn eftirfylgdarprófa}

Eftir fyrsta íhlutunartímabilið, sem var sex vikur, var lagt fyrir í fyrsta skipti eftirfylgdarpróf 1 lesfimi og sjónrænum orðaforða. Pá sýndu nokkur börn í samanburðarhópi annaðhvort svipaðan árangur eða lakari en börnin í íhlutunarhópnum. Sammerkt var með pessum börnum að pau höfðu ýmist skimast í áhættu 2 eða óvissu í einum eða tveimur páttum skimunarinnar. Tekin var sú ákvörðun að bæta pessum börnum í íhlutunarhópinn. Eftir eftirfylgdarpróf 1 voru pví 14 börn í íhlutunarhópi. Í töflu 2 sjást niðurstöður úr pessum tveimur prófum, hverjir voru í íhlutunarhópi eftir lesskimun og svo peir sem bættust við eftir fyrsta eftirfylgdarpróf. Dau börn sem ekkert stendur við voru í samanburðarhópi. 
Tafla 2. Lesfimi og sjónrænn orðaforði, fyrsta eftirfylgdarpróf lagt fyrir í desember.

\begin{tabular}{|c|c|c|c|c|c|c|}
\hline \multicolumn{3}{|c|}{ Lesfimi } & \multicolumn{2}{|c|}{ Sjónrænn orðaforði } & \multicolumn{2}{|c|}{ Íhlutunarhópur } \\
\hline Barn & Leshraði & Raðeinkunn & Leshraði & Raðeinkunn & Eftir lesskimun & $\begin{array}{l}\text { Eftir fyrsta } \\
\text { eftirfylgdarpróf }\end{array}$ \\
\hline 1 & 30 & 35 & 28 & 65 & & \\
\hline 2 & 27 & 35 & 28 & 65 & & \\
\hline 3 & 26 & 35 & 27 & 62 & & \\
\hline 4 & 13 & 7 & 15 & 28 & & Stafapekking \\
\hline 5 & 20 & 12 & 19 & 40 & & \\
\hline 6 & 22 & 22 & 18 & 37 & & \\
\hline 7 & 29 & 35 & 27 & 62 & Hljóðkerfisvitund & \\
\hline 8 & 20 & 12 & 24 & 54 & Málproski & \\
\hline 9 & 83 & 94 & 83 & 99 & & \\
\hline 10 & 31 & 46 & 29 & 66 & & \\
\hline 11 & 33 & 46 & 32 & 73 & & \\
\hline 12 & 46 & 68 & 37 & 81 & & \\
\hline 13 & 15 & 7 & 18 & 37 & & Hljóðkerfisvitund \\
\hline 14 & 33 & 46 & 35 & 78 & & \\
\hline 15 & 11 & 7 & 13 & 24 & & \\
\hline 16 & 12 & 7 & 15 & 28 & & Hljóðkerfisvitund \\
\hline 17 & 8 & 4 & 9 & 16 & Stafapekking & \\
\hline 18 & 25 & 22 & 24 & 54 & & \\
\hline 19 & 8 & 4 & 8 & 13 & & Hljóðkerfisvitund \\
\hline 20 & 11 & 7 & 14 & 26 & Stafapekking & \\
\hline 21 & 12 & 7 & 4 & 5 & & Stafapekking \\
\hline 22 & 21 & 22 & 19 & 40 & & \\
\hline 23 & 44 & 64 & 35 & 78 & & \\
\hline 24 & 24 & 22 & 23 & 52 & & \\
\hline 25 & 20 & 12 & 21 & 46 & & \\
\hline 26 & 26 & 35 & 29 & 66 & & \\
\hline 27 & 21 & 22 & 23 & 52 & Hljóðkerfisvitund & \\
\hline 28 & 27 & 35 & 14 & 26 & & \\
\hline 29 & 20 & 12 & 23 & 52 & & \\
\hline 30 & 69 & 85 & 73 & 97 & & \\
\hline 31 & 23 & 22 & 17 & 34 & & \\
\hline 32 & 48 & 68 & 33 & 74 & & \\
\hline 33 & 15 & 7 & 14 & 26 & Stafapekking & \\
\hline 34 & 14 & 7 & 14 & 26 & Hljóðkerfisvitund & \\
\hline 35 & 59 & 78 & 58 & 95 & & \\
\hline 36 & 18 & 12 & 13 & 24 & & \\
\hline 37 & 12 & 7 & 4 & 5 & & Hljóðkerfisvitund \\
\hline 38 & 14 & 7 & 11 & 21 & Hljóðkerfisvitund & \\
\hline 39 & 28 & 35 & 24 & 54 & & \\
\hline
\end{tabular}


Lágmarksviðmið, sem sett var fyrir lesfimi og sjónrænan orðaforða, var raðeinkunn 35. Tafla 2 sýnir að 16 börn náðu lágmarksviðmiði fyrir lesfimi strax í desember og par af eitt barn sem var í íhlutunarhópi (barn nr. 7). Degar skoðaðar eru niðurstöður fyrir hin börnin í íhlutunarhópunum var eitt barn með raðeinkunn 4, fjögur börn með raðeinkunn 7, eitt barn með raðeinkunn 12 og eitt barn með raðeinkunn 22.

Degar samanburðarhópurinn er skoðaður voru sjö börn sem sýndu svipaðan eða lakari árangur en íhlutunarhópurinn. Sex af peim höfðu ýmist skimast í áhættu 2 eða óvissu í einum eða tveimur páttum í lesskimuninni í upphafi vetrar. Dessum börnum var bætt við íhlutunarhópinn. Pau börn sem bættust við íhlutunarhópinn fengu kennslu í samræmi við pann pátt sem pau höfðu skimast 1 áhættu 2 eða óvissu. Dau börn sem höfðu skimast í tveimur báttum fengu íhlutun í peim pætti sem pau skimuðust í meiri áhættu. Sjöunda barnið var utan áhæettu í öllum premur páttum lesskimunarinnar og var vandi pess af öðrum toga en barnanna í íhlutunarhópnum. Petta barn fékk aðstoð inni í bekk hjá umsjónarkennara.

Mynd 1 sýnir hver fjöldi barna var í samanburðarhópi og íhlutunarhópi eftir lesskimun og hver fjöldinn var í pessum tveimur hópum eftir fyrsta eftirfylgdarpróf.

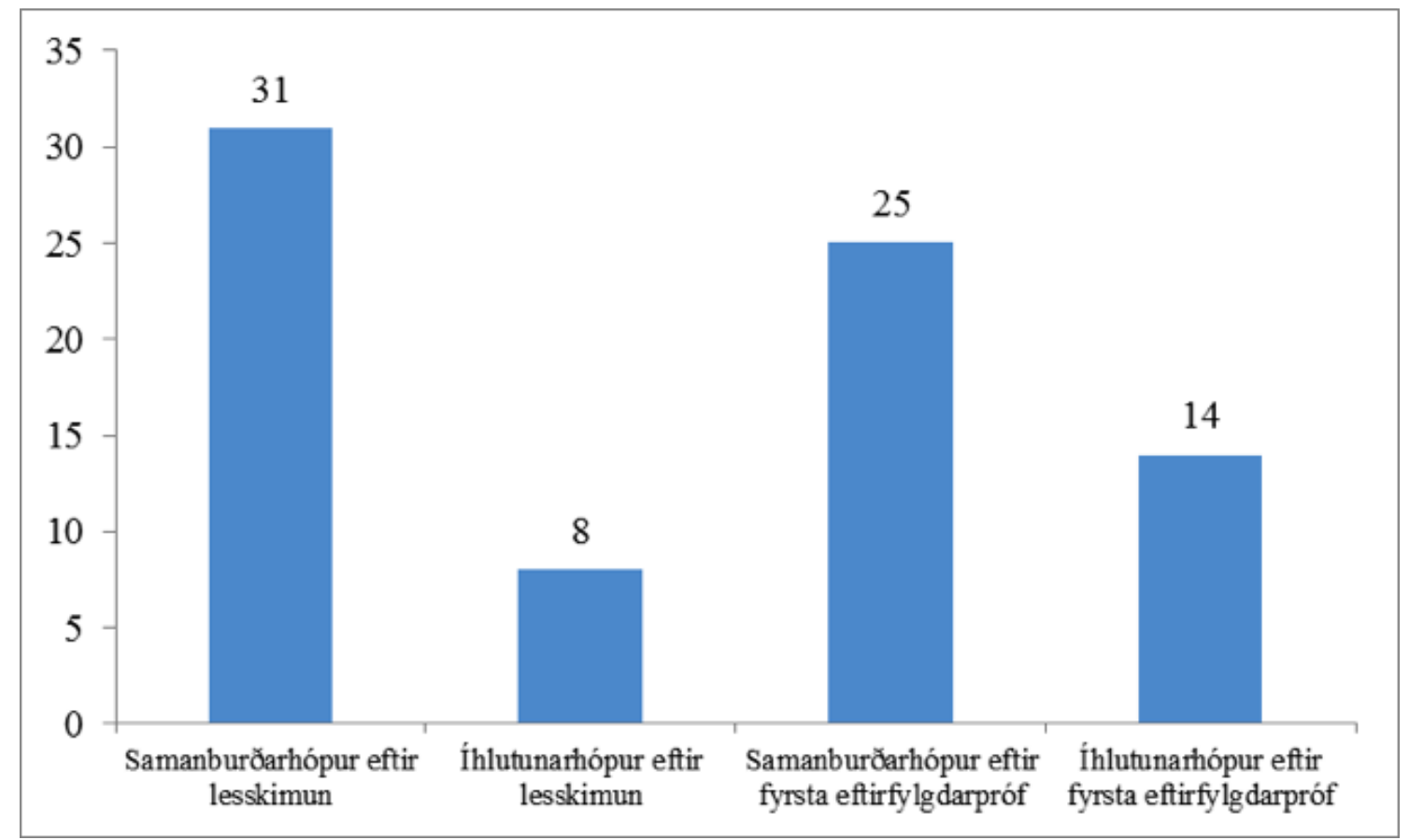

Mynd 1. Fjöldi í samanburðarhópi og íhlutunarhópi.

Fjöldi barna í samanburðarhópi eftir lesskimun var 31 og í íhlutunarhópi 8. Eftir fyrsta eftirfylgdarpróf hafði fjölda barna í samanburðarhópi fækkað í 25 en fjölgað í 14 í íhlutunarhópi.

\section{Fylgni og forsendur skiptrar dreifigreiningar}

Gerð var skipt dreifigreining á mun meðaltala milli hópa og innan hópa fyrir endurteknar mælingar með einu líkani fyrir hverja háða breytu, eða alls fjögur líkön. Háðu breyturnar voru lesfimi mæld sem leshraði annars vegar og raðeinkunn hins vegar og síðan sjónrænn orðaforði mældur sem leshraði og raðeinkunn. Athugað var hvort líkönin fullnægðu hvert um sig forsendum slíkrar dreifigreiningar. Forsendur eru um fylgni milli óháđra breyta, um normaldreifingu háđra breyta, sambærilegar dreifitölur háđra breyta, fjarveru útlaga og nægjanlegan fjölda í úrtakinu. 
Fylgnitafla (tafla 3) fyrir tengsl háđu breytanna í líkönunum sýnir að sterk fylgni er á milli fylgibreytanna í líkaninu, pað er mælinga á lestrarfærni og sjónrænum orðaforða.

Tafla 3. Fylgnitafla háðra breyta.

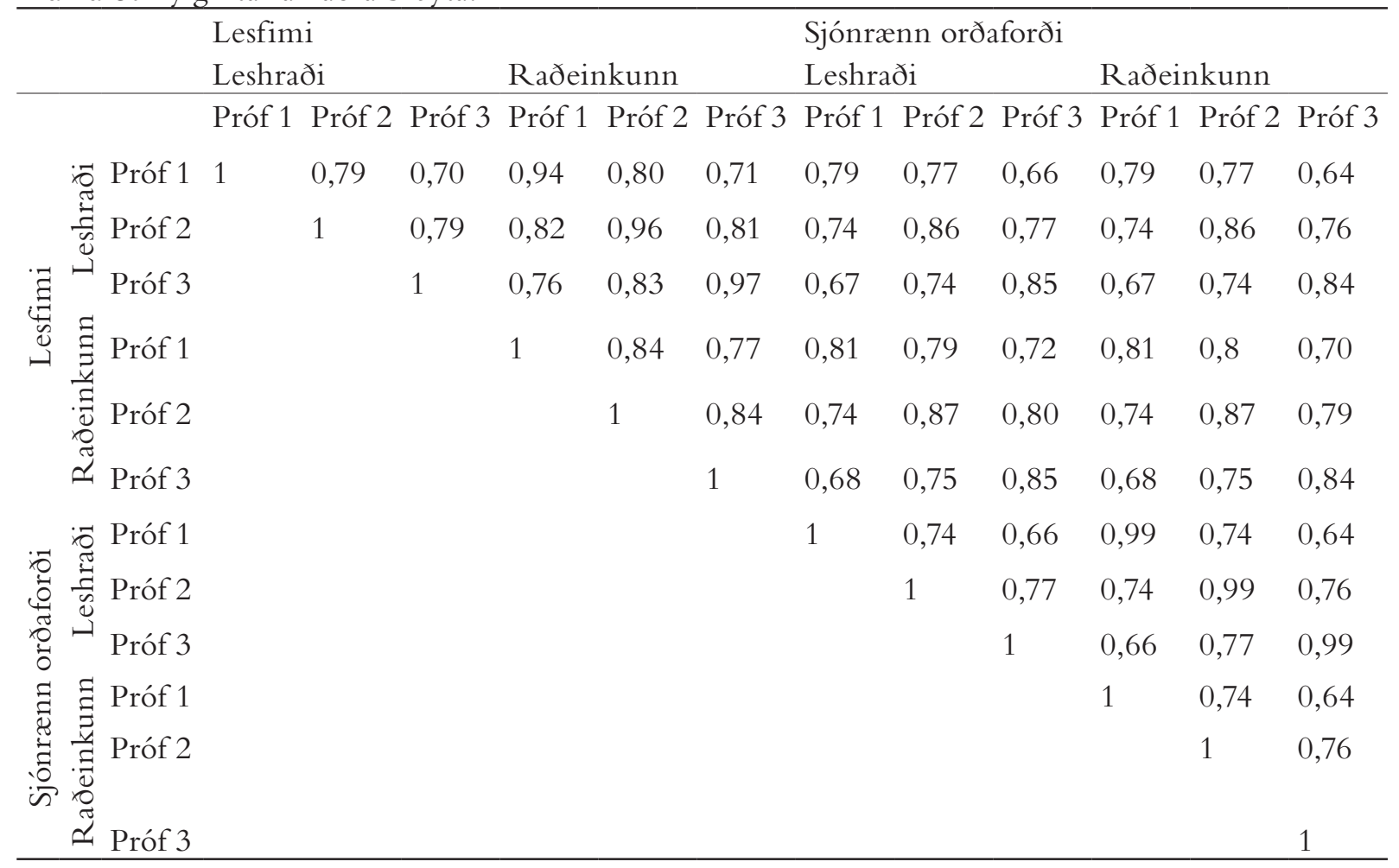

Athugun á normaldreifingu á mælingu á lestrarfærni á hverri mælingu, sem voru 12 skipt á hópana tvo eða alls 24 dreifingar, sýndi að samkvæmt Shapiro-Wilk-prófi voru 13 peirra normaldreifðar en 11 voru pað ekki. Frávik frá normaldreifingu fólust í tilhneigingu til jákvæðrar skekkju (e. skewness) á fyrri tíma mælinganna en neikvæðri skekkju á síðari mælitímum. Skekkjuna má að einhverju leyti skýra með pví að verið er að bera saman dreifingu innan sömu hópa sem miðast við stöðlun að vori. Í fámennu úrtaki má einnig búast við frávikum af pessu tagi en líta verður á pau sem takmörkun á rannsókninni.

Aftur á móti eru dreifigreiningar polnar gagnvart pví að forsendan um samsvarandi dreifitölur (e. homogeneity of variance) sé brotin, sé munur á hópastærðum ekki of mikill (Pallant, 2013) pó vissulega sé umdeilt hvort pessi lýsing standist (Tabachnick og Fidell, 2007; Field, 2018). Fylgnitöflur dreifitalna líkananna fjögurra teljast sambærilegar, sem kemur fram í pví að viðeigandi tölfræðipróf fyrir mun á milli peirra (e. Box's test of equality of covariance matrices) sýnir ekki tölfræðilega marktæk frávik fyrir líkönin fjögur (Pallant, 2013). ${ }^{1}$ Forsendunni um samsvarandi dreifitölur er pví fullnægt.

Útlagar voru ekki til staðar í gagnasafninu.

Aflgreining sýnir að nægjanlega margir voru í hópunum í úrtakinu. Sé leitað miðlungsáhrifa $\left(\eta^{2}=0,25\right)$ að gefnum $5 \%$ líkum á höfnunarmistökum $(\alpha)$ fyrir tvo hópa á premur mælingum kemur í ljós að líkur á fastheldnimistökum $(1-\beta)$ eru aðeins 7\% pegar reiknað er með öllum 39 sem voru í úrtakinu. Væri gerð krafa um að miðað væri við sama fjölda í báðum hópunum, sem hér yrðu pá tveir hópar með 14 pátttakendum eða 28 alls, væru líkur á fastheldnimistökum 19\%. Fullnægjandi er að miða við 5\% líkur á höfnunarmistökum og 20\% líkur á fastheldnimistökum eins og hér er gert (Field, 2018). Dað eykur afl rannsóknarinnar verulega að taka tillit til pess að mælingarnar eru endurteknar hjá hverjum einstaklingi frekar en að meðhöndla pær sem aðskildar mælingar. Đað gerir pessa rannsókn með svo fáum einstaklingum mögulega.

\footnotetext{
Gerð var sams konar greining á gögnunum með pví að draga kvaðratrót af fylgibreytunum premur í hverju líkani. Líkönin uppfylltu enn frekar forsendur greiningarinnar bæði hvað varðar normaldreifingu fylgibreyta og samsvörun dreifitölu. Ákveðið var pó að nota ekki pessar breytur vegna sýnilegra rjáfuráhrifa (e. ceiling effect) innan háðu breytanna fyrir raðeinkunnir.
} 


\section{Dreifigreiningar á framvindu lesfimi}

Eftirfylgdarpróf í lesfimi var lagt fyrir prisvar sinnum. Mynd 2 sýnir meðaltal leshraða úr lesfimi hjá samanburðarhópi og íhlutunarhópi samkvæmt líkani 1. Ef samanburðarhópurinn er skoðaður koma í ljós samfelldar framfarir. Meðaltal leshraða var tæplega 33 eftir próf 1, tæplega 48 eftir próf 2 og tæplega 60 eftir próf 3. Dað sama gildir um íhlutunarhópinn. Dar voru framfarir sem sjást á pví að meðaltal leshraða var tæplega 15 eftir próf 1, tæplega 26 eftir próf 2 og rúmlega 35 eftir próf 3.

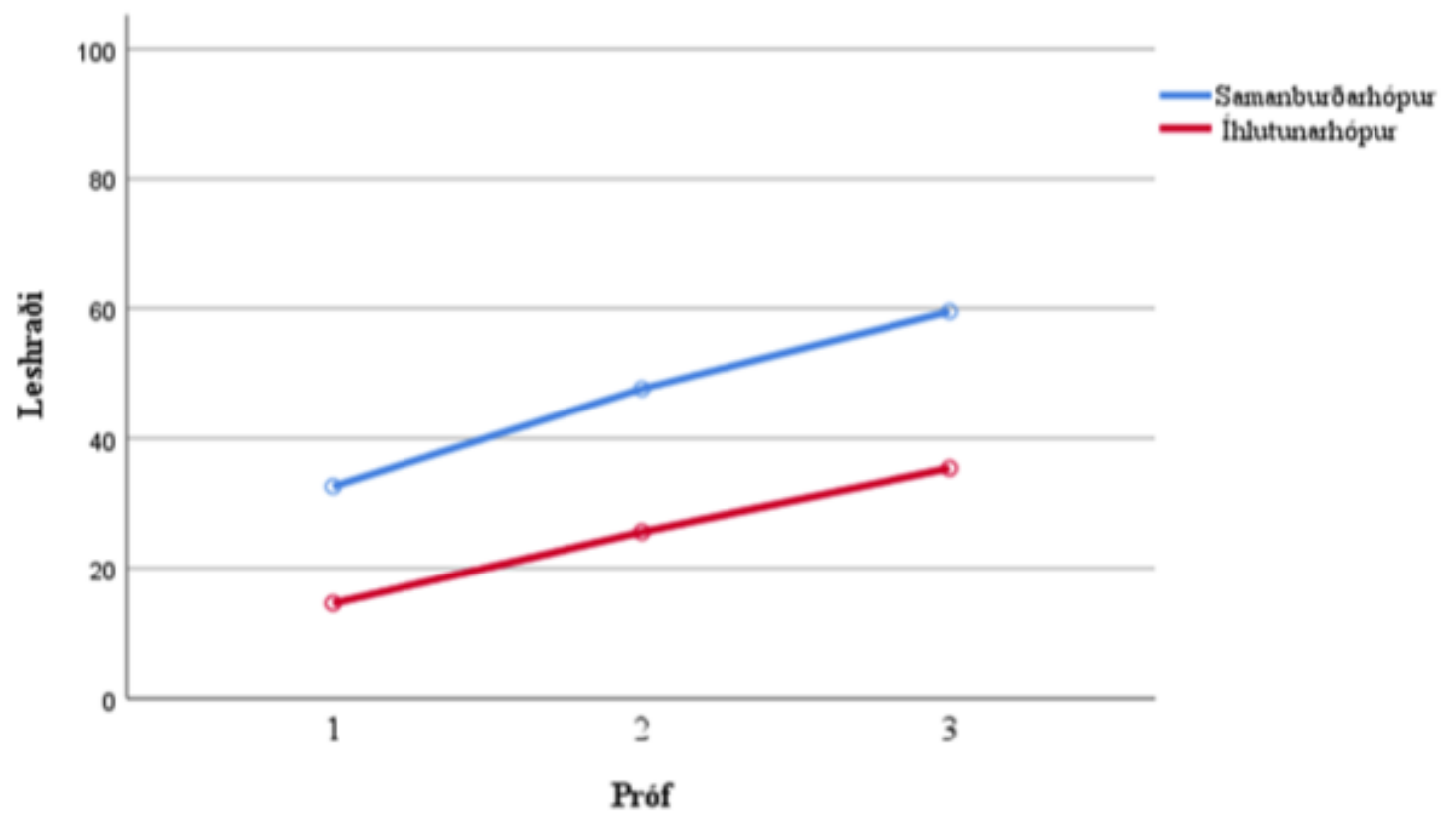

Mynd 2. Líkan 1. Meðaltal leshraða úr lesfimi 1, 2 og 3.

Fram kom aukinn leshraði á endurteknum mælingum hjá báðum hópunum. Munurinn á meðaltölunum á milli hópanna fór pó vaxandi á öllum premur mælitímum; tími $1 \Delta 18$, tími 2 $\Delta 22$, tími $3 \Delta 24$ eins og sjá má í töflu 4.

Tafla 4. Líkan 1. Lesfimi mæld sem leshraði.

\begin{tabular}{lccccccc}
\hline & & \multicolumn{2}{c}{ Íhlutunarhópur } & \multicolumn{3}{c}{ Samanburðarhópur } & Munur á hópunum \\
& Fjöldi & Meðaltal & Staðalfrávik & Fjöldi & Meðaltal & Staðalfrávik & $\Delta$ meðaltala \\
\hline Próf 1 & 14 & 14,6 & 5,6 & 25 & 32,6 & 16,9 & 17,99 \\
Próf 2 & 14 & 25,6 & 10,1 & 25 & 47,6 & 24,4 & 22,07 \\
Próf 3 & 14 & 35,4 & 12,8 & 25 & 59,5 & 25,7 & 24,16 \\
\hline
\end{tabular}

Degar skoðuð er breyting á frammistöđu yfir tímabilið hjá báđum hópum pá sýnir Wilks’ Lambda fyrir megináhrif breytinga á mun á frammistöðu hópanna milli mælinga að samvirkniáhrifin (e. interaction effect) eru ekki tölfræðilega marktæk $F(2,36)=1,24, p=0,301$. Munurinn milli hópanna breyttist pví ekki tölfræðilega marktækt.

Í ljósi pessa var athugað hvort megináhrif fyrir breytingar á frammistöðu yfir tímabilið væru tölfræðilega marktæk. Wilks' Lambda sýnir tölfræðilega marktæka breytingu $F(2,36)=69,06$, $p<0,001$. Баð varð pví breyting á frammistöðu nemenda milli pessara priggja mælipunkta hjá báđum hópunum. Áhrifastærð breytinganna er mikil, $\eta^{2}=0,79$ (Cohen, 1988). 
Munurinn á frammistöðu hópanna yfir tímabilið var tölfræðilega marktækur par sem $F(1,37)=$ $12,2, p=0,001$ og skýrð dreifing á mun var mikil eða $\eta^{2}=0,25$. Mynd 2 sýnir pá raunverulegan mun á hópunum og raunverulegar framfarir hjá báđum en að bilið milli peirra breytist ekki tölfræðilega marktækt.

Mynd 3 sýnir samanburð á meðaltali raðeinkunna úr lesfimi hjá samanburðarhópi og íhlutunarhópi. Ef samanburðarhópurinn er skoðaður var meðaltal raðeinkunna tæplega 39 eftir próf 1, rúmlega 59 eftir próf 2 og 72 eftir próf 3. Í íhlutunarhópnum var meðaltal raðeinkunna 10 eftir próf 1 , rúmlega 27 eftir próf 2 og tæplega 47 eftir próf 3.

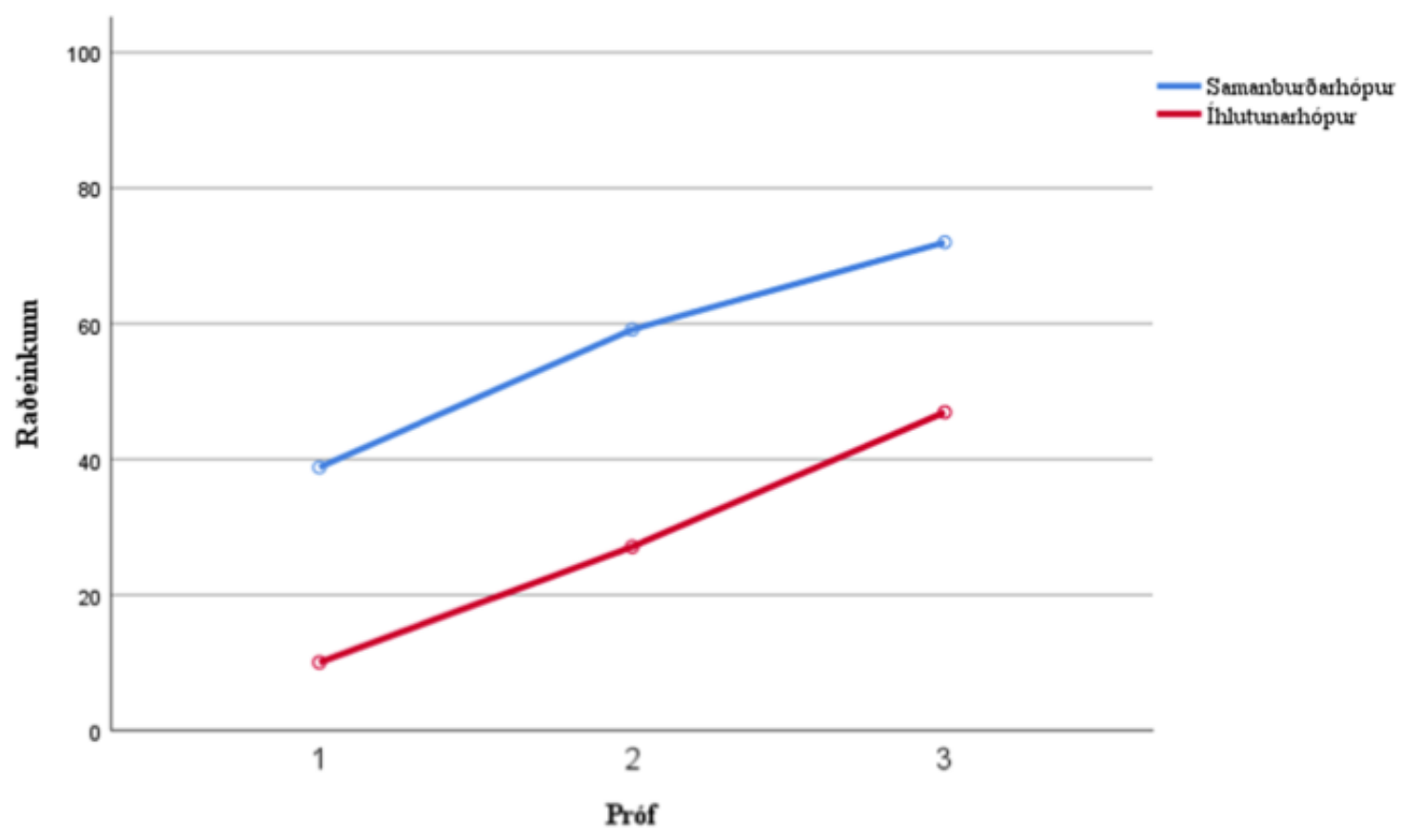

Mynd 3. Líkan 2. Meðaltal raðeinkunna úr lesfimi 1, 2 og 3.

Fram komu hækkandi raðeinkunnir á endurteknum mælingum hjá báđum hópunum. Eins og áđur hefur komið fram miðast stöðlunin við frammistöðu að vori og pví eðlilegt að raðeinkunnirnar hækki. Fram kom breytilegur munur á meðaltölum hópanna, vaxandi á annarri mælingu en minnkaði á priðju mælingu; tími $1 \Delta 29$, tími $2 \Delta 32$, tími $3 \Delta 25$, eins og sjá má í töflu 5 .

Tafla 5. Líkan 2. Lesfimi mæld sem raðeinkunn.

\begin{tabular}{cccccccc}
\hline & \multicolumn{3}{c}{ Íhlutunarhópur } & \multicolumn{3}{c}{ Samanburðarhópur } & Munur á hópunum \\
& Fjöldi & Meðaltal & Staðalfrávik & Fjöldi & Meðaltal & Staðalfrávik & $\Delta$ meðaltala \\
\hline Próf 1 & 14 & 10,0 & 8,4 & 25 & 38,8 & 24,6 & 28,8 \\
Próf 2 & 14 & 27,1 & 20,4 & 25 & 59,1 & 24,4 & 32,05 \\
Próf 3 & 14 & 46,9 & 20,9 & 25 & 72,0 & 21,3 & 25,07 \\
\hline
\end{tabular}

Wilks' Lambda fyrir megináhrif fyrir breytingar á mun á frammistöđu hópanna milli mælinga sýnir að pau eru ekki tölfræðilega marktæk: $F(2,36)=1,95, p=0,157$.

Megináhrif fyrir breytingar á frammistöðu yfir tímabilið voru tölfræðilega marktæk. Wilks' Lambda sýnir tölfræðilega marktæka breytingu: $F(2,36)=100,55, \mathrm{p}<0,001$. Breyting varð á frammistöðu nemenda milli pessara priggja mælipunkta hjá báðum hópunum. Áhrifastærð breytinganna er mikil, $\eta^{2}=0,85$.

Munurinn á frammistöðu hópanna yfir tímabilið var tölfræðilega marktækur par sem $F(1,37)=$ $17,8, \mathrm{p}<0,001$ og skýrð dreifing á mun var mikil eða $\eta^{2}=0,32$. 


\section{Niðurstöður lesfimi barna í íhlutunarhópi}

Á mynd 4 sést leshraði allra barna í íhlutunarhópi (notuð eru númer sem börnin fengu í rannsókninni sbr. töflu 3) úr öllum premur prófunum í lesfimi.

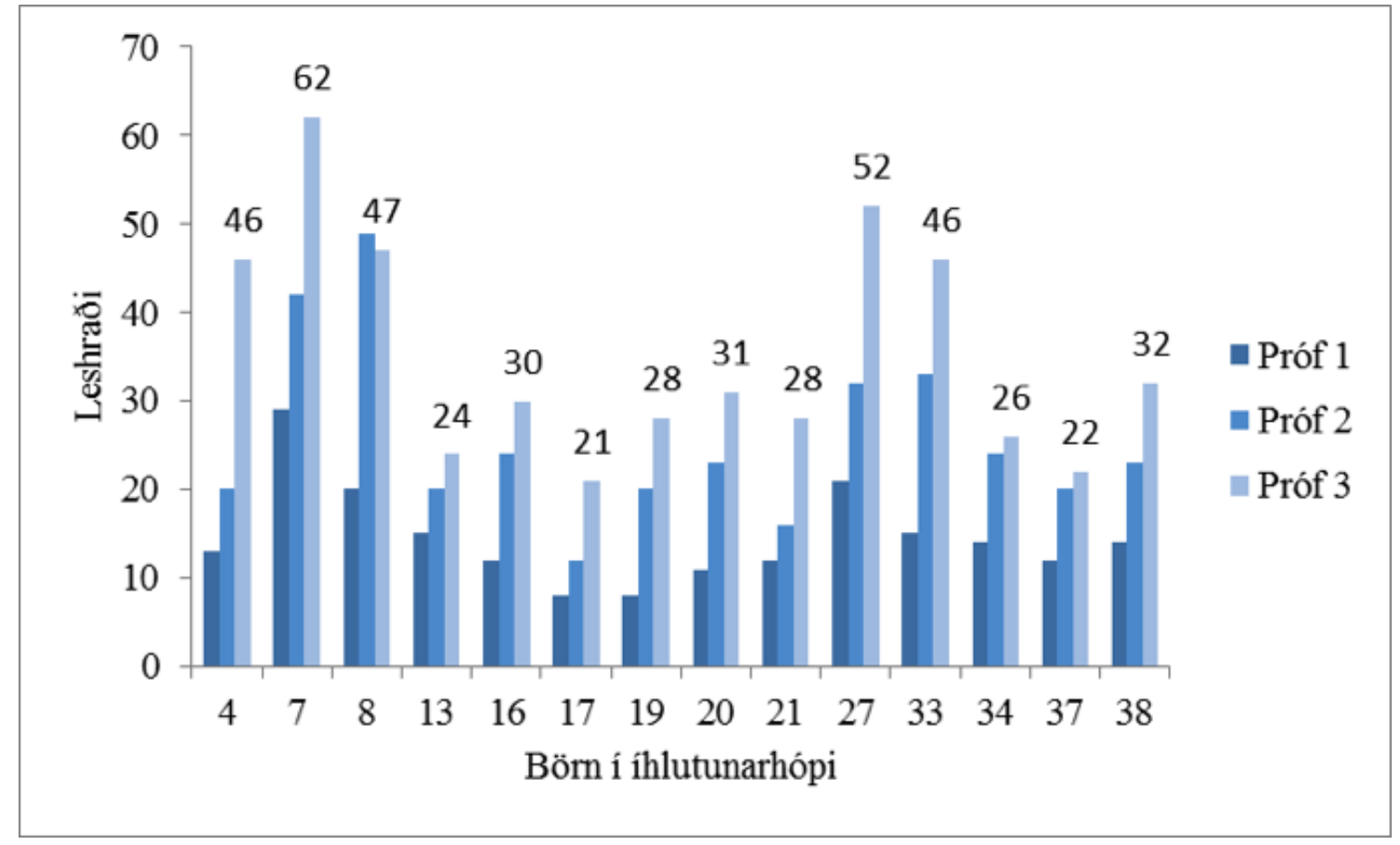

Mynd 4. Lesfimi mæld sem leshraði hjá börnum í íhlutunarhópi.

Eins og sjá má bættu öll börn í íhlutunarhópnum leshraða sinn á tímabilinu og mörg peirra umtalsvert.

Á mynd 5 sést lesfimi mæld sem raðeinkunn allra barna í íhlutunarhópi úr öllum premur prófunum.

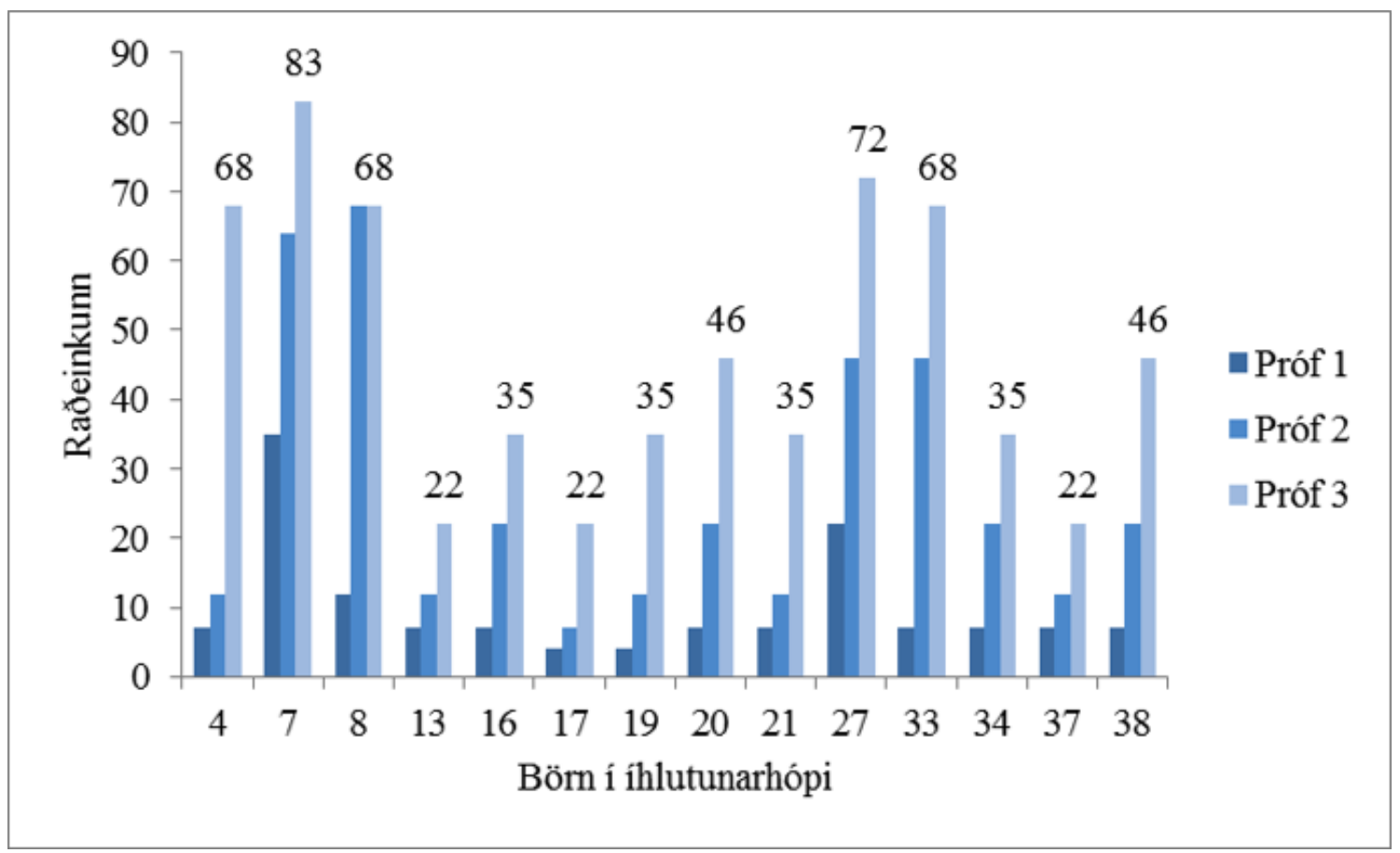

Mynd 5. Lesfimi mæld sem raðeinkunn hjá börnum í íhlutunarhópi. 
Prjú börn í hópnum fengu raðeinkunn 22 á síðasta prófinu og náđu pví ekki raðeinkunn 35, sem var sett sem lágmarksviðmið. Detta jafngildir pví að tæplega 8\% barna í árganginum hafi ekki náð lágmarksviðmiði eftir öll prjú íhlutunartímabilin. Eitt barn náði lágmarksviðmiði eftir próf 1, fjögur börn til viðbótar náðu pví eftir próf tvö og sjö börn eftir próf 3 .

\section{Dreifigreiningar á framvindu sjónræns orðaforða}

Eftirfylgdarpróf í sjónrænum orðaforða var líkt og í lesfimi lagt fyrir prisvar sinnum yfir veturinn. Mynd 6 sýnir samanburð á meðaltali leshraða úr sjónrænum orðaforða hjá samanburðarhópi og íhlutunarhópi yfir tímabilið. Helsta niðurstaðan er að framfarir urðu hjá báðum hópum. Ef samanburðarhópurinn er skoðaður var meðaltal leshraða rúmlega 30 eftir próf 1, tæplega 41 eftir próf 2 og tæplega 55 eftir próf 3 . Í íhlutunarhópnum var meðaltal leshraða rúmlega 14 eftir próf 1, tæplega 21 eftir próf 2 og tæplega 32 eftir próf 3.

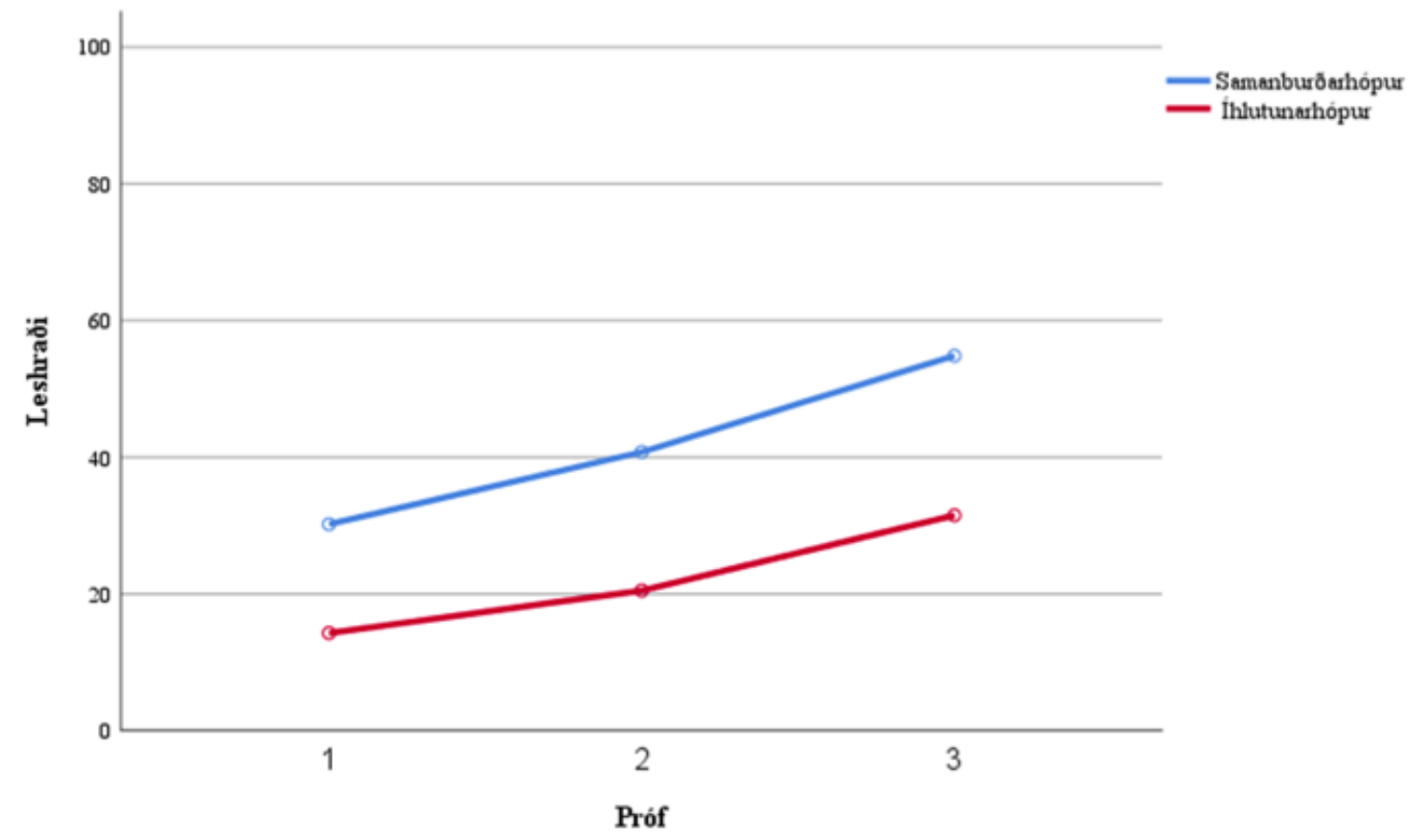

Mynd 6. Líkan 3. Meðaltal leshraða úr sjónrænum orðaforða 1, 2 og 3.

Dað kom pví fram aukinn leshraði mældur sem sjónrænn orðaforði á endurteknum mælingum hjá báđum hópunum. Fram kom vaxandi munur á meðaltölum hópanna á öllum premur mælitímum; tími $1 \Delta 16$, tími $2 \Delta 20$, tími $3 \Delta 23$, eins og sjá má í töflu 6 .

Tafla 6. Líkan 3. Sjónrænn orðaforði mældur sem leshraði.

\begin{tabular}{cccccccc}
\hline & & \multicolumn{2}{c}{ Íhlutunarhópur } & \multicolumn{3}{c}{ Samanburðarhópur } & Munur á hópunum \\
& Fjöldi & Meðaltal & Staðalfrávik & Fjöldi & Meðaltal & Staðalfrávik & $\Delta$ meðaltala \\
\hline Próf 1 & 14 & 14,3 & 6,9 & 25 & 30,2 & 17,3 & 15,91 \\
Próf 2 & 14 & 20,5 & 8,6 & 25 & 40,8 & 22,8 & 20,26 \\
Próf 3 & 14 & 31,5 & 14,1 & 25 & 54,8 & 28,2 & 23,34 \\
\hline
\end{tabular}

Wilks' Lambda fyrir megináhrif fyrir breytingar á mun á frammistöðu milli mælinga sýnir аð pau eru ekki tölfræðilega marktæk: $F(2,36)=1,07, p=0,354$. Munurinn á milli hópanna breyttist pví ekki tölfræðilega marktækt. 
Wilks’ Lambda sýndi tölfræðilega marktæka breytingu á frammistöðu fyrir tímabilið í heild: $F(2,36)=32,91, \mathrm{p}<0,001$. Раð varð breyting á frammistöðu nemenda milli pessara priggja mælipunkta hjá báđum hópunum. Áhrifastærð breytinganna er mikil, $\eta^{2}=0,65$.

Munurinn á frammistöðu hópanna yfir tímabilið var tölfræðilega marktækur par sem $F(1,37)=$ $10,46, p=0,003$ og skýrð dreifing á mun var mikil eða $\eta^{2}=0,22$.

Mynd 7 sýnirsamanburðá meðaltali raðeinkunna úr lesfimi hjá samanburðarhópi og íhlutunarhópi. Ef samanburðarhópurinn er skoðaður var meðaltal raðeinkunna rúmlega 59 eftir próf 1, rúmlega 72 eftir próf 2 og tæplega 84 eftir próf 3. Í íhlutunarhópnum var meðaltal raðeinkunna tæplega 29 eftir próf 1, rúmlega 43 eftir próf 2 og tæplega 64 eftir próf 3.

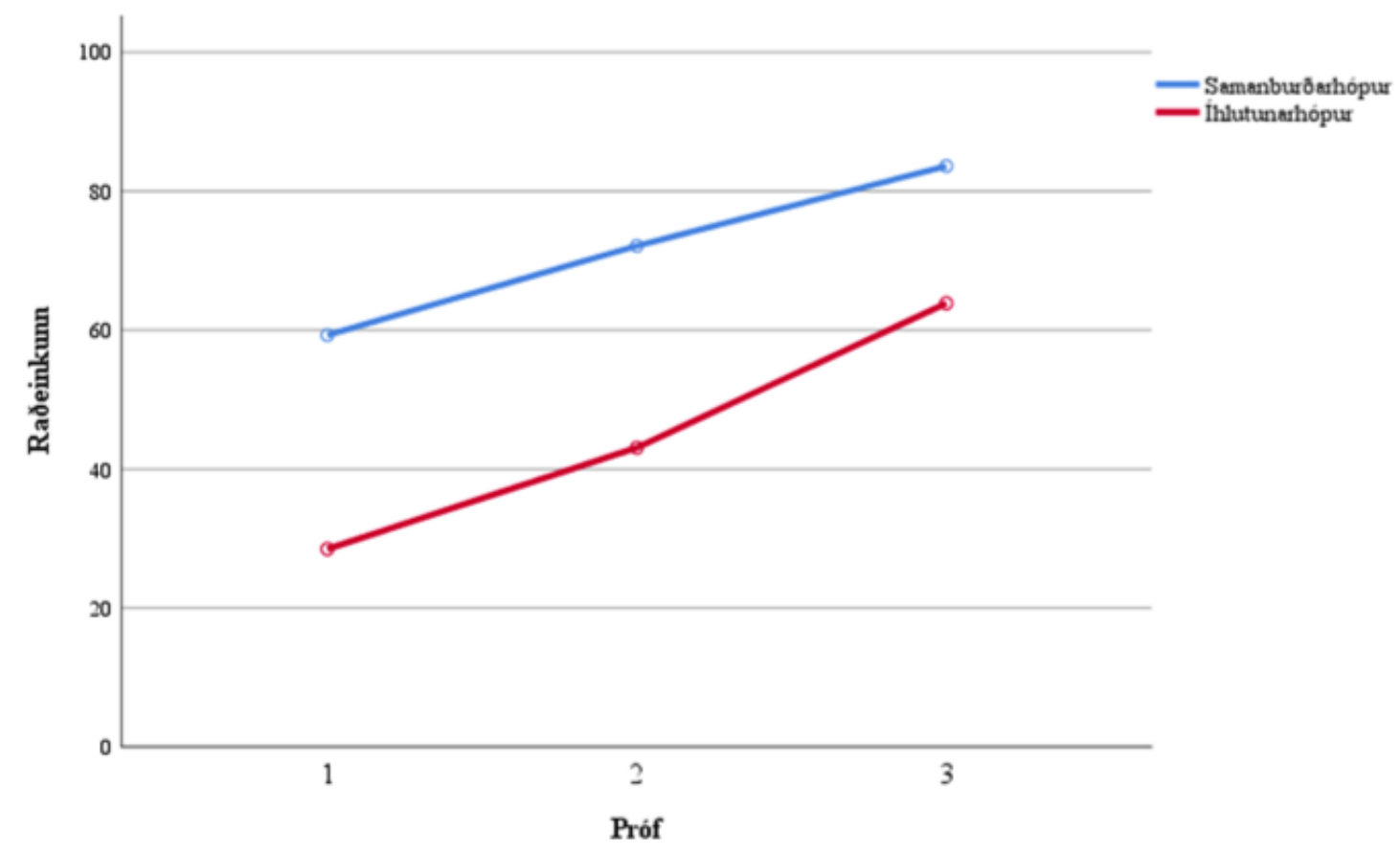

Mynd 7. Líkan 4. Meðaltal raðeinkunna úr sjónrænum orðaforða 1, 2 og 3.

Fram komu hækkandi raðeinkunnir í sjónrænum orðaforða á endurteknum mælingum hjá báđum hópunum. Fram kom minnkandi munur á meðaltölum hópanna á öllum premur mælitímum; tími $1 \Delta 31$, tími $2 \Delta 29$, tími $3 \Delta 20$ eins og sjá má í töflu 7.

Tafla 7. Líkan 4. Sjónrænn orðaforði mældur sem raðeinkunn. ${ }^{2}$

\begin{tabular}{cccccccc}
\hline & & \multicolumn{2}{c}{ Íhlutunarhópur } & \multicolumn{3}{c}{ Samanburðarhópur } & Munur á hópunum \\
& Fjöldi & Meðaltal & Staðalfrávik & Fjöldi & Meðaltal & Staðalfrávik & $\Delta$ meðaltala \\
\hline Próf 1 & 14 & 28,5 & 17,5 & 25 & 59,3 & 22,2 & 30,78 \\
Próf 2 & 14 & 43,1 & 19,9 & 25 & 72,1 & 21,0 & 29,05 \\
Próf 3 & 14 & 63,9 & 22,8 & 25 & 83,6 & 17,3 & 19,74 \\
\hline
\end{tabular}

Wilks' Lambda fyrir megináhrif fyrir breytingar á mun á frammistöðu milli mælinga sýnir pó að pau voru ekki tölfræðilega marktæk: $F(2,36)=2,57, p=0,091$.

Wilks' Lambda sýndi tölfræðilega marktæka breytingu á frammistöðu fyrir tímabilið í heild: $F(2,36)=55,62, \mathrm{p}<0,001$. Раð varð pví breyting á frammistöðu nemenda milli pessara priggja mælipunkta hjá báđum hópunum. Áhrifastærð breytinganna er mikil, $\eta^{2}=0,76$.

\footnotetext{
2 Greining par sem háða breytan var raðbreyta (líkan 2 og líkan 4), umbreytt með pví að draga kvaðratrót peirra, sýndi að bilið á milli hópanna minnkaði tölfræðilega marktækt. Að öðru leyti var niðurstaðan sambærileg. Líklega er pessi tölfræðilega marktekt til komin vegna rjáfuráhrifa í mælingunni á háðu breytunni par sem margir nemendur í samanburðarhópnum voru við efri mörk kvarðans á síðustu mælingunni.
} 
Munurinn á frammistöðu hópanna var tölfræðilega marktækur par sem $F(1,37)=18,24, \mathrm{p}<$ 0,001 og skýrð dreifni munarins var mikil eða $\eta^{2}=0,33$.

\section{Niðurstöður sjónræns orðaforða barna í íhlutunarhópi}

Á mynd 8 sést leshraði allra barna í íhlutunarhópi úr öllum premur prófunum í sjónrænum orðaforða.

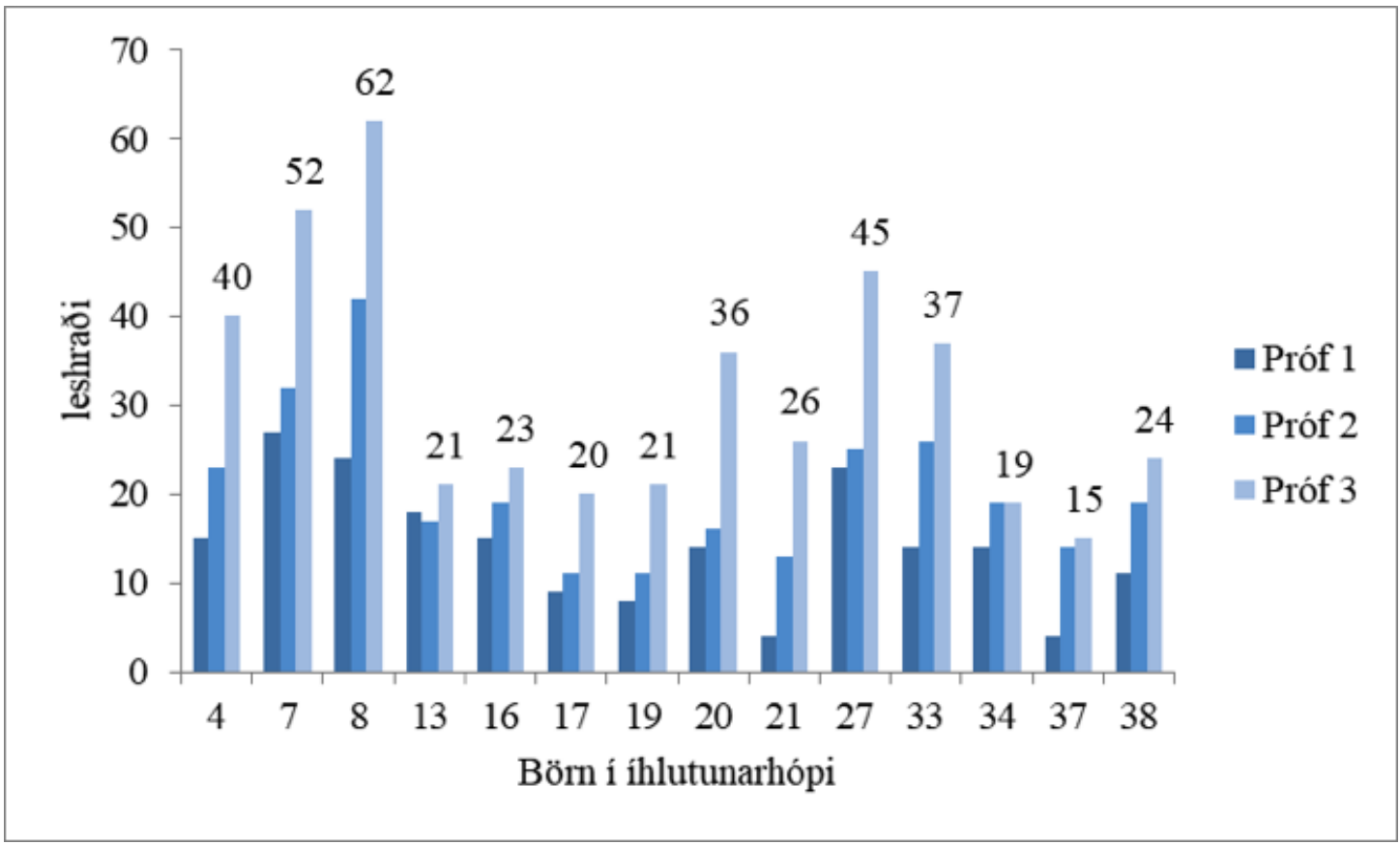

Mynd 8. Leshraði, sjónrænn orðaforði hjá börnum í íhlutunarhópi.

Eins og sjá má bættu öll börn í íhlutunarhópnum leshraða sinn í sjónrænum orðaforða á tímabilinu og mörg peirra bættu leshraða sinn umtalsvert.

Á mynd 9 sést sjónrænn orðaforði mældur sem raðeinkunn allra barna í íhlutunarhópi.

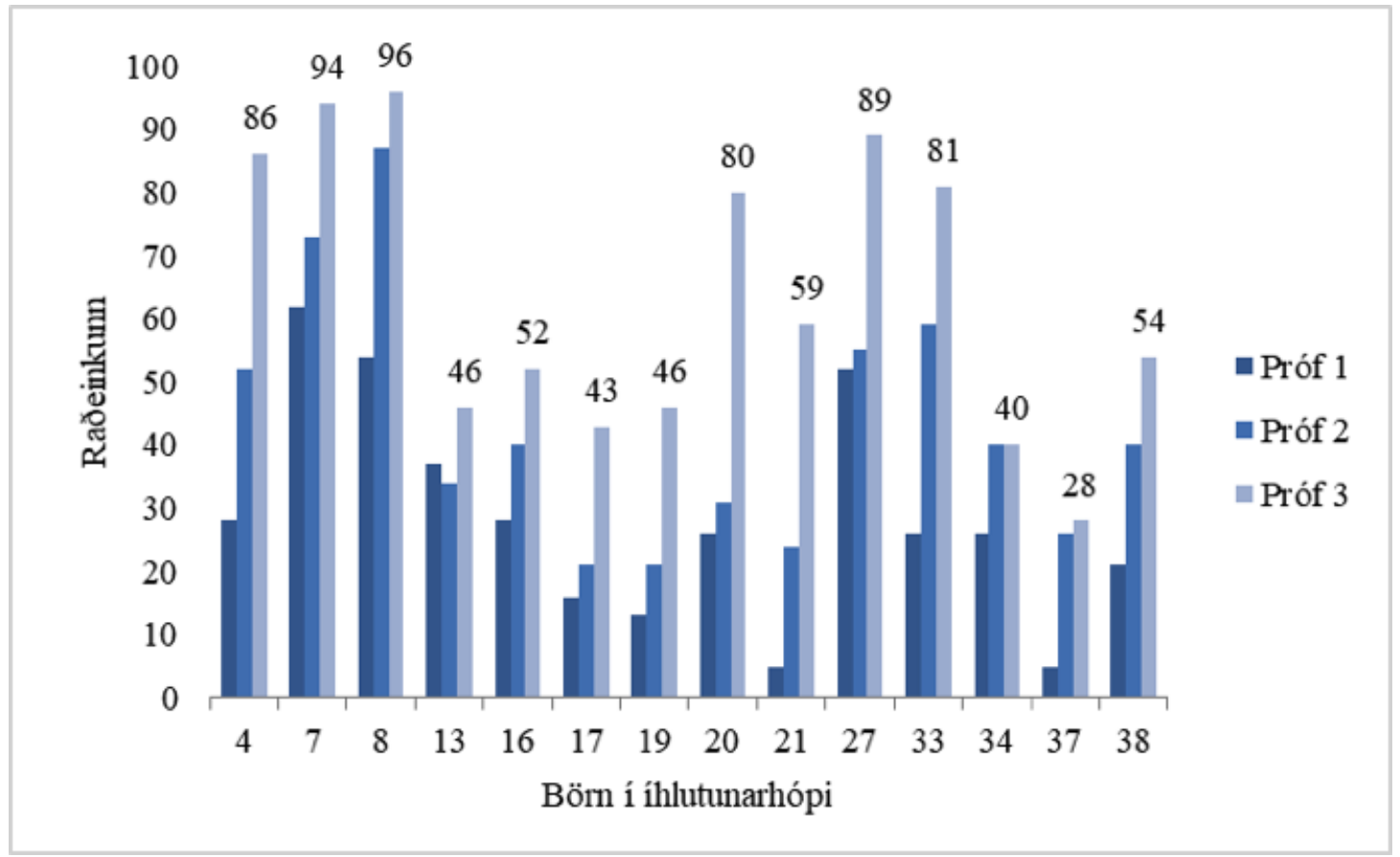

Mynd 9. Raðeinkunn, sjónrænn orðaforði hjá börnum í íhlutunarhópi. 
Einungis eitt barn náði ekki lágmarksviðmiði sem er raðeinkunn 35 eftir öll prjú prófin en pað er barn nr. 37, pað barn náði ekki heldur raðeinkunn 35 í lesfiminni. Detta jafngildir pví að tæplega 3\% barna í árganginum hafi ekki náð lágmarksviðmiði eftir öll prjú íhlutunartímabilin. Fjögur börn úr íhlutunarhópnum nádu raðeinkunn 35 strax eftir próf 1, fimm börn eftir próf 2 og fjögur börn eftir próf 3. Ef samanburðarhópurinn er skoðaður náðu öll börn nema fjögur pessu sama viðmiði strax eftir próf 1, prjú börn náðu viðmiðinu eftir próf 2 og eitt barn úr samanburðarhópnum náði viðmiðinu eftir próf 3.

\section{Umræður}

Í upphafi greinarinnar voru settar fram tvær rannsóknarspurningar. Fyrri spurningin var: Hver eru áhrif snemmtækrar íhlutunar, með Leið til leesis, á lestrarnám barna sem greinst hafa í áhættuhópi? Degar spurningin er skoðuð í ljósi niðurstaðna rannsóknarinnar má draga pá ályktun að áhrifin séu jákvæð á heildina litið. Börnin sýndu öll framfarir á tímabilinu og einungis prjú börn náðu ekki raðeinkunn 35 í lesfimi, sem var sett sem lágmarksviðmið áður en haldið var af stað, og eitt barn í sjónrænum orðaforða.

Seinni spurningin var: Er hægt með snemmtækri íhlutun í hljóðkerfisvitund, stafapekkingu og eflingu málproska, að minnka líkurnar á pví að börn sem eru í áhættuhópi dragist aftur úr jafnöldrum? Pegar spurningin er skoðuð í ljósi niðurstaðna rannsóknarinnar má álykta að svo sé. Íhlutunarhópur náði að halda í við framfarir samanburðarhóps.

\section{Lesfimi}

Degar lesfimin er skoðuð bættu bæði íhlutunar- og samanburðarhópurinn sig á tímabilinu. Dó kom fram breytilegur munur á meðaltölum fyrir raðeinkunnir hópanna milli mælinga, p.e.a.s. vaxandi munur var á annarri mælingu en svo minnkandi á priðju mælingu. Mögulega hefði getað dregið meira saman með hópunum ef gerðar hefðu verið fleiri mælingar yfir lengra tímabil. González-Valenzuela og Martín-Ruiz (2017) komust að peirri niðurstöðu í sinni rannsókn að framfarir íhlutunarhóps voru hraðari en samanburðarhóps eftir pví sem íhlutunartímabilunum fjölgaði, sem leiddi til minnkandi munar sem varð til pess að fyrrnefndi hópurinn nálgaðist hinn jafnt og pétt. Einnig má velta pví fyrir sér hvort börn í íhlutunarhópi hafi eðli málsins samkvæmt purft á meiri leiðsögn að halda í upphafi lestrarnámsins, og pví verið lengur að koma sér af stað í upphafi. Мeð öðrum orðum, börn í samanburðarhópnum höfðu forskot á börnin í íhlutunarhópnum í upphafi rannsóknar.

Breyting á frammistöđu nemenda í lesfimi í báđum hópum, á milli pessara priggja mælipunkta, er tölfræðilega marktæk, báđir hópar bættu sig á milli mælinga. Íhlutunarhópur náði að halda í við framfarir samanburðarhóps, en breyting á mun milli hópanna var ekki tölfræðilega marktæk. Tilgátu um að breyting yrði á mun á frammistöđu hópanna yfir tímabilið er pví hafnað. Samkvæmt kenningu Stanovich (1986) um Matteusar-áhrif má gera ráo fyrir að bil á milli peirra sem gengur vel í lestrarnámi og peirra sem gengur ekki vel breikki eftir bví sem tíminn líður. Í ljósi pessa má velta pví fyrir sér hver staða barnanna í íhlutunarhópnum hefði verið ef engin íhlutun hefði átt sér stað. Líkur eru á pví að bilið hefði aukist, samanber kenningu um Matteusar-áhrif, en ekki staðið í stað. Фаð að íhlutunarhópur nái að halda í við framfarir hjá samanburðarhópi pótt börnin nái ekki sömu frammistöðu og samanburðarhópur verður að teljast góður árangur. Í pessu samhengi er áhugavert að benda á að pað að færa börn úr samanburðarhópi sem höfðu sýnt minnstu framfarir styrkti í raun og veru stöðu samanburðarhópsins.

Degar niðurstöður í lesfimi eftir öll prjú prófin eru skoðaðar varðandi hvert barn í íhlutunarhópi náðu prjú börn, eða tæp 8\%, ekki raðeinkunn 35 sem var sett sem lágmarksviðmið. Engu að síður sýndu pau öll framfarir á tímabilinu og náðu raðeinkunn 22. Tvö pessara barna eiga pað sameiginlegt að hafa komið inn í íhlutunarhópinn eftir próf 1. Annað barnið hafði verið í áhættu 
2 í stafapekkingu og hljóðkerfisvitund og hitt í óvissu í hljóðkerfisvitund. Priðja barnið hafði verið í íhlutunarhópi frá upphafi par sem pað var í áhættu 1 í stafapekkingu. Mikill munur getur verið á milli einstaklinga hversu móttækilegir peir eru fyrir íhlutun og geta framfarir sumra verið undir væntingum. Rannsókn Torgesen (2002) sýndi að íhlutun skilaði ekki fullnægjandi árangri fyrir öll börn, um 5\% barna áttu enn við lestrarerfiðleika að stríða prátt fyrir mikla íhlutun í peim páttum sem pau voru með veikleika í. Í pessari rannsókn er hlutfallið tæp 8\% og pví örlítið hærra. Pess ber pó að geta að úrtakið í rannsókninni er lítið og pví vegur hver einstaklingur pungt í samanburði.

Megintilgangur íhlutunarinnar var að bregðast markvisst við hugsanlegum vanda 1 upphafi lestrarnámsins og koma í veg fyrir að bilið á milli pessara tveggja hópa ykist á tímabilinu sem náði yfir fyrsta árið í grunnskóla. Framfarirnar hjá hópunum tveimur voru sambærilegar og munurinn ekki marktækur. Ekki er hægt að horfa fram hjá pví að börn sem eiga í erfiðleikum 1 upphafi lestrarnáms sýna oft hægari framfarir en önnur börn. Раð að börn í íhlutunarhópi haldi í við samanburðarhópinn og að bilið á milli pessara tveggja hópa breikki ekki er út af fyrir sig viðunandi árangur. Pá er vert að taka fram að lestrarnám er langhlaup sem á sér stað yfir lengra tímabil en pessi rannsókn nádi til. Hugsanlegt er að með áframhaldandi íhlutun og gódu utanumhaldi með börnunum í íhlutunarhópnum sé hægt að halda í við framfarir hjá samanburðarhópi og jafnvel minnka bilið á milli pessara tveggja hópa.

\section{Sjónrænn orðaforði}

Sjónrænn orðaforði var mældur sem leshraði. Líkt og í lesfiminni kom fram aukinn leshraði og hækkandi raðeinkunnir fyrir báða hópa. Fram kom vaxandi munur á meðaltölum fyrir leshraða en minnkandi munur á meðaltölum fyrir raðeinkunnir. Dví er tilgátu um að breyting yrði á mun á frammistöðu hópanna yfir tímabilið hafnað. Bilið á milli hópanna mælt með raðeinkunn minnkaði með endurteknum mælingum. Баð er áhugavert í ljósi pess að börn sem eiga í lestrarerfiðleikum eiga erfiðara en önnur börn með að læra orð sjónrænt. Pau taka lengri tíma í að bera kennsl á pau sem heild og lesa pekkt orð hægar en börn sem ekki glíma við lestrarerfiðleika (Ehri, 2007). Degar horft er til kenningar Stanovich (1986) um Matteusar-áhrif ætti bilið á milli hópanna tveggja pví að breikka á kostnað íhlutunarhópsins. Pess ber pó að geta að eitt barn í samanburðarhópi hafði ekki möguleika á að bæta sig eftir próf 1 og annað barn sömuleiðis eftir próf 2 par sem hámarksárangri hafði pá pegar verið náð. Darna gæetti rjáfuráhrifa í samanburðarhópi.

Degar niðurstöður einstakra barna í íhlutunarhópi eru skoðaðar náði eitt barn, eða tæp 3\%, ekki raðeinkunn 35 í lok íhlutunar, sem var sett sem lágmarksviðmið. Dað náði ekki heldur lágmarksviðmiði í lesfiminni. Barnið sýndi engu að síður framfarir á tímabilinu, var með raðeinkunn 5 í prófi 1 og 28 í prófi prjú í sjónrænum orðaforða. Detta barn kom í íhlutunarhóp eftir próf 1 og hafði verið í áhættu 2 í hljóðkerfisvitund og stafapekkingu. Líkt og kom fram í umræðu um lesfimi bendir Torgesen (2002) á að prátt fyrir íhlutun barna sem eiga í lestrarerfiðleikum pá eiga 5\% peirra enn í erfiðleikum. Sambærilegt hlutfall fyrir sjónrænan orðaforða er tæp 3\% sem er undir pví viðmiði. Dess ber enn sem fyrr að geta að úrtakið í pessari rannsókn er lítið og pví hefur hver einstaklingur mikið vægi í samanburði.

Eins og áđur hefur komið fram er pað út af fyrir sig árangur pegar hópur barna sem á í lestrarvanda nær að halda í við framfarir samanburðarhóps, án pess að bilið á milli pessara tveggja hópa breikki. Dað að fram komi minnkandi munur á meðaltölum hópanna fyrir raðeinkunn eru áhugaverðar niðurstöður pví pað merkir að framfarir íhlutunarhóps séu meiri en samanburðarhóps og pá dregur saman með pessum hópum. Á ekki lengri tíma en pessum fyrsta vetri í lestrarkennslu er petta ágætis árangur sem vekur ákveðnar vonir um framhaldið hjá pessum börnum. Detta er pó einungis upphafið á lestrarnámi pessara barna og margt gott getur gerst í framhaldinu ef áfram er unnið á sambærilegan hátt með Leið til lasis. 


\section{Samantekt á umræðu}

Niðurstöður rannsóknarinnar benda til pess að áhrif snemmtækrar íhlutunar með Leið til lacsis séu jákvæð á heildina litið. Niðurstöður benda einnig til að með snemmtækri íhlutun megi minnka líkurnar á að börn sem eru í áhættuhópi dragist aftur úr jafnöldrum par sem íhlutunarhópur náđi að halda í við framfarir samanburðarhóps. Öll börn í íhlutunarhópi sýndu framfarir á tímabilinu, einungis prjú börn náðu ekki lágmarksviðmiði í lesfimi og eitt í sjónræna orðaforðanum. Degar teknar eru saman niðurstöður fyrir lesfimi og sjónrænan orðaforða pá náðu um 5\% barna ekki lágmarksviðmiði prátt fyrir íhlutun. Рað er sambærileg niðurstaða og kemur fram í öðrum rannsóknum (Torgesen, 2002).

Tvö af peim premur börnum, sem náðu ekki lágmarksviðmiði sem sett var í upphafi rannsóknar, eiga pað sameiginlegt að hafa komið inn í íhlutunarhópinn eftir próf 1. Annað pessara barna náði ekki lágmarksviðmiði í lesfimi og sjónrænum orðaforða. Vert er að velta fyrir sér hvort tímamörk hafi skipt máli hjá pessum tveimur börnum par sem pau höfðu ekki fengið nema tvö íhlutunartímabil af premur. González-Valenzuela og Martín-Ruiz (2017) sýndu fram á í sinni langtímarannsókn að eftir pví sem á leið og íhlutunartímabilum fjölgaði urðu framfarir hjá íhlutunarhópi hraðari. Driðja barnið í rannsókninni sem ekki náđi lágmarksviðmiðum var í íhlutunarhópi frá upphafi vegna veikleika í stafapekkingu. Dessu barni rétt svo dugði fyrsti veturinn til að læra alla stafina og hljóð peirra og festa pá í minni til að geta kallað pá fram hratt og örugglega. Баð er meginforsenda pess að geta lesið af öryggi og geta byrjað að pjálfa lesfimina. Ekkert annað barn í rannsókninni tók jafnlangan tíma í petta ferli.

Vert er að velta fyrir sér peirri spurningu hver staða barna í íhlutunarhópi hefði verið ef engin íhlutun hefði átt sér stað strax við upphaf lestrarnámsins. Sýnt hefur verið fram á að ef íhlutun í lestrarkennslu á að bera árangur parf hún að vera snemmtæk. Áhrif af íhlutun sem fer fram í lok leikskóla og í upphafi grunnskóla eru talin jákvæð og auka hæfni barnanna (González-Valenzuela og Martín-Ruiz, 2017; Hanselman og Borman, 2013; Lane o.fl., 2009; Partanen og Siegel, 2014). Eins hefur verið sýnt fram á að íhlutun sem hefst ekki fyrr en í 3. bekk eða seinna skilar hvorki jákvæðum né neikvæðum áhrifum (Hanselman og Borman, 2013). Í pessari rannsókn má leiða að pví líkum að án íhlutunar hefði bilið milli íhlutunar- og samanburðarhóps breikkað samkvæmt kenningu um Matteusar-áhrif (Stanovich, 1986). Ef tekin hefði verið ákvörðun um að bíða og sjá til, eins og algengt var á árum áđur (Steinunn Torfadóttir, 2011b) hefði dýrmætur tími farið til spillis og líkur á að íhlutun hefði haft minni áhrif eftir pví sem lengur væri beðið með hana og jafnvel ekki skilað neinum árangri ef beðið hefði verið með hana fram í 3. bekk eða lengur.

\section{Lokaorð}

Leiðarljós í gegnum alla vinnuna við petta verkefni hefur verið kenning Stanovich (1986) um Matteusar-áhrif. Баð að geta hjálpað peim börnum sem eiga á hæettu að lenda í erfiðleikum með lestrarnámið áður en pau standa frammi fyrir peim er gríðarlega mikilvægt. Helsta markmiðið var að bilið myndi ekki aukast á milli pessara tveggja hópa sem tóku pátt í rannsókninni, og helst að pað myndi minnka. Í umfjöllun hér að framan hefur verið sýnt fram á að bilið milli íhlutunarhóps og samanburðarhóps jókst ekki og sýndu öll börnin góðar framfarir. Samkvæmt samantekt Sideridis (2011) stuðla Matteusar-áhrifin að pví að auka við pann mun sem er á börnum í upphafi skólagöngu. Dví er nauðsynlegt að veita peim börnum sem standa lakar pá aðstoð sem pau purfa frá upphafi svo hægt sé að vinna gegn peim. Niðurstöður rannsóknarinnar benda til pess að áhrif snemmtækrar íhlutunar með Leið til loesis séu jákvæð á heildina litið. Рað gefur ástæðu til að haldið sé áfram að vinna með Leið til lasis, bæði með peim börnum sem purfa áframhaldandi íhlutun eftir fyrsta árið í grunnskóla en einnig nýjum árgöngum sem hefja skólagöngu á hverju hausti. 


\section{Early intervention in 1st grade for children with reading disabilities}

It is important for success in learning, and life in general, to gain an early grasp of reading. There is a connection between reading skills and social and economic success later in life. Being an active participant in the life and culture of a nation requires sound reading skills and is the foundation of a person's life. Every effort must be made to improve the position of children who are at a disadvantage in reading, to use the most effective methods and to intervene as soon as possible (Mennta- og menningarmálaráðuneytið [Ministry of Education and Culture], 2013; Lane, Pullen, Hudson \& Konold, 2009). Early intervention is a specialized approach that seeks to answer the question of what is best for the individual and why. It is also considered important to initiate intervention as early as possible, or as soon as suspicion arises about difficulties (Steinunn Torfadóttir, 2011b; Tryggvi Sigurðsson, 2004, 2008). Stanovich (1986) presented a theory of Matthew effects in reading, which means that the rich will become richer and poor poorer. When children are successful in reading, they read more than children who are not. They are constantly expanding their knowledge and reading skills, and the gap between those who do well in learning to read and those who do not widens as the school progresses.

This is a study of the effects of early interventions in teaching children how to read. Leid til loesis [Road to Literacy] is a support system designed to assist teachers in the first grades in elementary school to (a) identify children at risk of developing reading disabilities, and (b) organize interventions and assess their effects. The support system consists of a manual, a screening test, and follow-up tests in reading and visual vocabulary.

The study format was a non-equivalent control group design. The study involved screening for potential reading disabilities in first grade children in one elementary school and providing them with appropriate interventions in phonological awareness, letter knowledge and language development. The intervention periods were three, and the effect of the intervention was assessed by follow-up tests in reading and visual vocabulary.

It was hypothesized that through effective and powerful intervention at the beginning of the 1st grade, possible reading difficulties in children at risk may be reduced or prevented. Answers were sought to the following research questions: What are the effects of early interventions, using Leið til loesis, on literacy among children at risk of developing reading disabilities? By using targeted instructions in phonological awareness, letter knowledge and language development, can the odds of these children falling behind their peers be reduced?

When reading skills were evaluated, differences in group performance over the period were not statistically significant. The hypothesis that group performance changes over the period is, therefore, rejected. Changes in student performance in both groups, between these three measurement points, were, however, statistically significant; both groups improved between measurements and the intervention group managed to keep up with the control group.

When visual vocabulary was evaluated, differences in group performance over the period were statistically significant. However, the hypothesis that group performance changes over the period is rejected. Changes in student performance in both groups, between these three measurement points, were statistically significant; both groups improved between measurements and the intervention group managed to keep up with the control group. 
The results of the study indicate that the effect of early intervention with Leid til locsis is positive. All children in the intervention group showed progress. Stanovich's theory of Matthew effects was taken into consideration, where children with reading disabilities are presumed to fall behind the others, and the gap between the two groups is presumed to expand over time. According to the results of the study, the gap between the groups did not increase and the intervention group managed to keep up with the progress of the control group.

Key words: Reading, reading disabilities, predictive value, early intervention.

\section{Um höfundana}

Elva Eir Pórólfsdóttir (elvaeir@akmennt.is) er verkefnastjóri sérkennslu í Giljaskóla á Akureyri og stundakennari við Háskólann á Akureyri. Hún hefur lokið B.Ed.prófi í kennarafræðum og M.A.-prófi í menntunarfræðum. Rannsóknin sem pessi grein byggist á var liður í meistaranámi hennar. Elva Eir hefur starfað á öllum stigum grunnskólans. Helstu verkefni hennar eru sérkennsla á yngsta stigi og teymisvinna í stoðpjónustu skólans.

Guðmundur Engilbertsson (ge@unak.is) er lektor við kennaradeild hug- og félagsvísindasviðs Háskólans á Akureyri (HA). Hann hefur lokið B.Ed.-prófi í kennarafræði og M.Ed.-prófi í menntunarfræði við HA og er doktorsnemi í menntavísindum við Háskóla Íslands. Guðmundur hefur starfað við grunn- og tónlistarskóla og hefur um árabil verið ráđgjafi í próunarstarfi í læsi. Helstu viðfangsefni hans í kennslu og rannsóknum lúta að orðaforða, læsi til náms og námsog kennslufræði.

Dorlákur Axel Jónsson (thorlakur@unak.is) er aðjunkt við Háskólann á Akureyri. Hann er í doktorsnámi á Menntavísindasviði Háskóla Íslands og rannsakar námsgengi framhaldsskólanema. Porlákur er cand. mag. í sagnfræði og pjóðfélagsfræði frá Kaupmannahafnarháskóla 1994.

\section{About the authors}

Elva Eir Dórólfsdóttir (elvaeir@akmennt.is) is a project manager of special education at Giljaskóli in Akureyri and part-time lecturer at the University of Akureyri. She holds a B.Ed. degree in Education from the University of Akureyri and M.A.-degree in Educational Studies from the University of Akureyri. The study on which this article is based was conducted in partial fulfilment of her master's degree. Elva Eir has worked as a primary and a secondary school teacher. Her interest is special education teaching at early elementary level and additional support for students.

Guðmundur Engilbertsson (ge@unak.is) is an assistant professor at the Faculty of Education in the School of Humanities and Social Sciences at the University of Akureyri. He holds a B.Ed.-degree in Education from the University of Akureyri, an M.Ed. degree in Educational Studies from the University of Akureyri and is currently a doctoral student (Ph.D.) at the University of Iceland. His teaching and research interest includes vocabulary learning and teaching, literacy for learning and learning and teaching methods.

Dorlákur Axel Jónsson (thorlakur@unak.is) is an adjunct lecturer at the University of Akureyri, Iceland. He is a doctoral student in the School of Education at the University of Iceland, Reykjavík, studying educational attainment at upper secondary school level. Dorlákur completed a cand. mag. degree from the University of Copenhagen in 1994. 


\section{Heimildir}

Ásthildur Bj. Snorradóttir. (2010). Að byrja nógu snemma - markviss kennsla fyrir börn sem eiga í erfiðleikum með mál og lestur. Talfraðingurinn, 21(1), 20-22.

Carroll, J. M., Bowyer-Crane, C., Duff, F. J., Hulme, C. og Snowling, M. J. (2011). Developing language and literacy: Effective intervention in early years. Malden, MA: John Wiley.

Catts, H.W., Fey, M. E., Tomblin, J. B. og Zhang, X. (2002). A longitudinal investigation of reading outcomes in children with language impairments. Journal of Speech, Language, and Hearing Research, 45, 1142-1157. doi:10.1044/1092-4388(2002/093)

Cohen, J. (1988). Statistical power analysis for the behavioural sciences (2. útg.). Hillsdale: Lawrence Erlbaum Associates.

Cohen, L., Manion, L. og Morrison, K. (2000). Research methods in education (5. útg.). London: Routledge Falmer.

Ehri, L. C. (2002). Reading processes, acquisition, and instructional implications. Í G. Reid og J. Wearmouth (ritstjórar), Dyslexia and literacy: Theory and practice (bls. 167-185). Chichester: John Wiley and sons.

Ehri, L. C. (2007). Development of sight word reading: Phases and findings. Í M. J. Snowling og C. Hulme (ritstjórar), The science of reading: A handbook (bls. 135-154). Oxford: Blackwell.

Elliot, J. G. og Grigorenko, E. L. (2014). The dyslexia debate. New York: Cambridge University Press.

Faul, F., Erdfelder, E., Lang, A.-G. og Buchner,A. (2007). G^Power:A flexible statistical power analysis program for the social, behavioral, and biomedical sciences. Behavior Research Methods, 39(2), 175-191.

Field, A. (2018). Discovering statistics using IBM SPSS. Los Angeles: Sage.

Foorman, B., Herrera, S., Petscher,Y., Mitchell,A. og Truckenmiller, A. (2015). The structure of oral language and reading and their relation to comprehension in kindergarten through grade 2. Reading and Writing, 28(5), 655-681. doi:10.1007/s11145-015-9544-5

González-Valenzuela,M. og Martín-Ruiz, I. (2017).Effects on reading of an early intervention program for children at risk of learning difficulties. Remedial and Special Education, 38(2), 67-75. doi:10.1177/0741932516657652

Guðrún Bjarnadóttir. (2004). Markviss málörvun - forspá um lestur. Tímarit um menntarannsóknir, 1(1), 185-194.

Hanselman, P. og Borman, G. D. (2013). The impacts of success for all on reading achievement in grades 3-5: Does intervening during the later elementary grades produce same benefits as intervening early? Educational Evaluation and Policy Analysis, 35(2), 237-251. doi:10.3102/0162373712466940

Helga Sigurmundsdóttir. (e.d.). Snemmtæk íhlutun. Lesvefurinn - um lasi og lestrarerfiðleika. Sótt af http:// lesvefurinn.hi.is/snemmtaek_ihlutun $\% 20$

Helga Sigurmundsdóttir. (2011a). Niðurstöður skimunar - hvað svo? Í Steinunn Torfadóttir (ritstjóri), Leið til laesis: Lesskimun fyrir fyrsta bekk grunnskóla - handbók (bls. 45-62). Reykjavík: Háskóli Íslands, Rannsóknarstofa um proska, mál og læsi, Námsmatsstofnun.

Helga Sigurmundsdóttir. (2011b). Að pjálfa lesfimi. Í Steinunn Torfadóttir (ritstjóri), Leið til lasis: Lesskimun fyrir fyrsta bekk grunnskóla - handbók (bls. 93-128). Reykjavík: Háskóli Íslands, Rannsóknarstofa um proska, mál og læsi, Námsmatsstofnun.

Hrafnhildur Ragnarsdóttir. (2004). Málproski barna við upphaf skólagöngu: Sögubygging og samloðun í frásögnum 165 fimm ára barna - almenn einkenni og einstaklingsmunur. Uppeldi og menntun, 13(2), 9-31.

Jóhanna Einarsdóttir, Ingibjörg Símonardóttir og Amalía Björnsdóttir. (2011). Langtímarannsókn á forspárgildi athugana á málproska: Frá leikskólaaldri til fullorðinsára. Netla - Veftímarit um uppeldi og menntun. Sótt af http://netla.hi.is/greinar/2011/ryn/006.pdf

Khun, M. R., Schwanenflugel, P. J. og Meisinger, B. M. (2010). Aligning theory and assessment of reading fluency: Automaticity, prosody, and definitions of fluency. Reading Research Quarterly, 45(2), 230-251. doi:10.1598/RRQ.45.2.4

Lane, H. B., Pullen, P. C., Hudson, R. F. og Konold, T. R. (2009). Identifying essential instructional components of literacy tutoring for struggling beginning readers. Literacy Research and Instruction, 48(4), 277-297. doi:10.1080/19388070902875173

Menntamálastofnun. (e.d.). Lesferill: Nýtt matstaki frá Menntamálastofnun sem metur loesi. Sótt af https://mms. is/sites/mms.is/files/kynning_a_lesferli.pdf 
Mennta- og menningarmálaráðuneytið. (2013). Aðalnámskrá grunnskóla:Almennur hluti 2011: Greinasvið 2013. Reykjavík: Höfundur.

Muter,V. (2006). The prediction and screening of children's reading difficulties. Í M. J. Snowling og J. Stackhouse (ritstjórar), Dyslexia, speech and language: A practitioner's handbook (2. útg.) (bls. 54-73). London: Whurr publishers.

Námsmatsstofnun. (e.d.-a). Eftirfylgnipróf LtL-Túlkun niðurstaðna. Sótt af http://www.namsmat.is/atest/doc/ lesskimun/LtL_tulkun_eftirfylgniprof a.pdf

Námsmatsstofnun. (e.d.-b). Leiðbeiningar um túlkun - Sjónreenn orðaforði og lesfimi. Sótt af http://www.namsmat. is/atest/doc/lesskimun/Leidbeiningar_um_tulkun_SO_og_LF.pdf

Pallant, J. (2013). SPSS survival manual: A step by step guide to data analysis using IBM SPSS (5. útg.). Maidenhead: McGraw Hill.

Partanen, M. og Siegel, L. S. (2014). Long-term outcome of the early identification and intervention of reading disabilities. Reading and Writing: An Interdisciplinary Journal, 27(4), 665-684. doi:10.1007/s11145-013-9472-1

Pence, K. L. og Justice, L. M. (2014). Language development from theory to practice. Harlow, Essex: Pearson.

Ragnheiður Harpa Arnardóttir. (2013). Megindlegar rannsóknir: Gerð rannsóknaráætlunar og yfirlit yfir helstu rannsóknarsnið. Í Sigríður Halldórsdóttir (ritstjóri), Handbók í aðferðafraði rannsókna (bls. 377-392). Akureyri: Háskólinn á Akureyri.

Rakel Magnúsdóttir. (2016). Reynsla og gagnsemi af stuðningskerfinu Leið til lassis (óútgefin meistaraprófsritgerð). Sótt af http://hdl.handle.net/1946/26046

Riley, J. (2006). Language and literacy 3-7: Creative approaches to teaching. London: Sage.

Rósa Eggertsdóttir og Dóra Björk Jónsdóttir. (2006). Lexía: Frææi um leshömlun, kenningar og mat. Akureyri: Háskólinn á Akureyri.

Scanlon, D. M., Anderson, K. L. og Sweeney, J. M. (2017). Early intervention for reading difficulties: The interactive strategies approach. New York: Guilford Press.

Schatschneider, C., Fletcher, J. M., Francis, D. J., Carlson, C. D. og Foorman, B. R. (2004). Kindergarten prediction of reading skills: A longitudinal comparative analysis. Journal of Educational Psychology, 96(2), 265-282. doi:10.1037/0022-0663.96.2.265

Sideridis, G. D. (2011). Exploring the presence of Matthew effects in learning disabilities. Journal of Learning Disabilities, 44(5), 399-401. doi:10.1177/0022219411410041

Sigurgrímur Skúlason og Jóhanna Ella Jónsdóttir. (2011). Stöðlun prófsins Leið til læsis: Lesskimun fyrir 1. bekk. Í Steinunn Torfadóttir (ritstjóri), Leið til lasis: Lesskimun fyrir fyrsta bekk grunnskóla - handbók (bls. 165-172). Reykjavík: Háskóli Íslands, Rannsóknarstofa um proska, mál og læsi, Námsmatsstofnun.

Snowling, M. J. (2006). Language skills and learning to read: The dyslexia spectrum. Í M. J. Snowling og J. Stackhouse (ritstjórar), Dyslexia, speech and language: A practitioner's handbook (2. útg.) (bls. 1-14). London: Whurr.

Snowling, M. J. (2013). Early identification and interventions for dyslexia: A contemporary view. Journal of Research in Special Educational Needs, 13(1), 7-14. doi:10.1111/j.1471-3802.2012.01262.x

Stanovich, K. E. (1986). Matthew effects in reading: Some consequences of individual differences in the acquisition of literacy. Reading Research Quarterly, 21(4), 360-407. Sótt af http://search.proquest.com/ docview/58181762?accountid $=49537$

Steinunn Torfadóttir. (2011a). Leið til læsis. Í Steinunn Torfadóttir (ritstjóri), Leið til loesis: Lesskimun fyrir fyrsta bekk grunnskóla - handbók (bls. 11-14). Reykjavík: Háskóli Íslands, Rannsóknarstofa um proska, mál og læsi, Námsmatsstofnun.

Steinunn Torfadóttir. (2011b). Hvernig má sporna við fyrirsjáanlegum lestrarvanda? Í Steinunn Torfadóttir (ritstjóri), Leið til loesis: Lesskimun fyrir fyrsta bekk grunnskóla - handbók (bls. 27-34). Reykjavík: Háskóli Íslands, Rannsóknarstofa um proska, mál og læsi, Námsmatsstofnun.

Steinunn Torfadóttir, Helga Sigmundsdóttir, Ásthildur Bj. Snorradóttir, Bjartey Sigurðardóttir, Jóhanna Ella Jónsdóttir og Sigurgrímur Skúlason. (2011). Leið til laesis: Lesskimun fyrir fyrsta bekk grunnskóla - leiðbeiningar um fyrirlögn. Reykjavík: Háskóli Íslands, Rannsóknarstofa um proska, mál og læsi, Námsmatsstofnun.

Tabchnick, B. G. og Fidell, L. S. (2007). Using multivariate statistics (5. útg.). Boston: Pearson. 
Torgesen, J. K. (2002). The prevention of reading difficulties. Journal of School Psychology, 40(1), 7-26. doi:10.1016/ S0022-4405(01)00092-9

Tryggvi Sigurðsson. (2004). Snemmtæk íhlutun fyrir ung börn með málhömlun. Talfrææðingurinn, 18(1), 5-7.

Tryggvi Sigurðsson. (2008). Snemmtæk íhlutun - yfirlit og áherslur. Í Bryndís Halldórsdóttir, Jóna G. Ingólfsdóttir, Stefán J. Hreiðarsson og Tryggvi Sigurðsson (ritstjórar), Droskahömlun barna: Orsakir - eðli - íhlutun (bls. 119-125). Reykjavík: Háskólaútgáfan.

Vellutino, F. R., Fletcher, J. M., Snowling, M.J. og Scanlon, D. M. (2004). Specific reading disability (dyslexia): What have we learned in the past four decades? Journal of Child Psychology and Psychiatry, 45(1), 2-40. doi:10.1046/j.0021-9630.2003.00305.x

Elva Eir Pórólfsdóttir, Guðmundur Engilbertsson og Porlákur Axel Jónsson. (2019).

Snemmtæk íhlutun í lestrarnámi í 1. bekk.

Netla - Veftímarit um uppeldi og menntun. Menntavísindasvið Háskóla Íslands.

Sótt af http://netla.hi.is/greinar/2019/ryn/10

DOI: https://doi.org/10.24270/netla.2019.10 